\title{
Review
}

\section{The Two-Faced Role of SIRT6 in Cancer}

\author{
Francesco Fiorentino ${ }^{1,+}+\mathbb{D}$, Vincenzo Carafa ${ }^{2,+}$, Gregorio Favale ${ }^{2}$, Lucia Altucci ${ }^{2, *}$ (D), Antonello Mai ${ }^{3, *}$ (D) \\ and Dante Rotili ${ }^{3, *(D)}$
}

Citation: Fiorentino, F.; Carafa, V.; Favale, G.; Altucci, L.; Mai, A.; Rotili, D. The Two-Faced Role of SIRT6 in Cancer. Cancers 2021, 13, 1156. https://doi.org/10.3390/ cancers13051156

Academic Editor: Alexander Arlt

Received: 28 January 2021

Accepted: 3 March 2021

Published: 8 March 2021

Publisher's Note: MDPI stays neutral with regard to jurisdictional claims in published maps and institutional affiliations.

Copyright: (c) 2021 by the authors. Licensee MDPI, Basel, Switzerland. This article is an open access article distributed under the terms and conditions of the Creative Commons Attribution (CC BY) license (https:/ / creativecommons.org/licenses/by/ $4.0 /)$.
1 Department of Chemistry, University of Oxford, South Parks Road, Oxford OX1 3QZ, UK; francesco.fiorentino@chem.ox.ac.uk

2 Department of Precision Medicine, Università degli Studi della Campania “L. Vanvitelli", 80138 Naples, Italy; vincenzo.carafa@unicampania.it (V.C.); gregorio.favale@unicampania.it (G.F.)

3 Department of Drug Chemistry \& Technologies, Sapienza University of Rome, P. le A Moro 5, 00185 Rome, Italy

* Correspondence: lucia.altucci@unicampania.it (L.A.); antonello.mai@uniroma1.it (A.M.); dante.rotili@uniroma1.it (D.R.); Tel.: +39-081-5667569 (L.A.); +39-06-49913392 (A.M.); +39-06-49913237 (D.R.)

+ Co-First Authors.

Simple Summary: Cancer therapy relies on the employment of different strategies aimed at inducing cancer cell death through different mechanisms, including DNA damage and apoptosis induction. One of the key regulators of these pathways is the epigenetic enzyme SIRT6, which has been shown to have a dichotomous function in cell fate determination and, consequently, cancer initiation and progression. In this review, we aim to summarize the current knowledge on the role of SIRT6 in cancer. We show that it can act as both tumor suppressor and promoter, even in the same cancer type, depending on the biological context. We then describe the most promising modulators of SIRT6 which, through enzyme activation or inhibition, may impair tumor growth. These molecules can also be used for the elucidation of SIRT6 function, thereby advancing the current knowledge on this crucial protein.

Abstract: Sirtuin 6 (SIRT6) is a NAD ${ }^{+}$-dependent nuclear deacylase and mono-ADP-ribosylase with a wide spectrum of substrates. Through its pleiotropic activities, SIRT6 modulates either directly or indirectly key processes linked to cell fate determination and oncogenesis such as DNA damage repair, metabolic homeostasis, and apoptosis. SIRT6 regulates the expression and activity of both pro-apoptotic (e.g., Bax) and anti-apoptotic factors (e.g., Bcl-2, survivin) in a context-depending manner. Mounting evidence points towards a double-faced involvement of SIRT6 in tumor onset and progression since the block or induction of apoptosis lead to opposite outcomes in cancer. Here, we discuss the features and roles of SIRT6 in the regulation of cell death and cancer, also focusing on recently discovered small molecule modulators that can be used as chemical probes to shed further light on SIRT6 cancer biology and proposed as potential new generation anticancer therapeutics.

Keywords: $\mathrm{NAD}^{+}$-dependent deacylases; cell death modulation; SIRT6 modulators; cancer; epigenetics

\section{Introduction}

Sirtuin 6 (SIRT6) is a crucial chromatin regulating protein belonging to the Sirtuin (SIRT) family, a class of broad-spectrum protein deacylases that utilize $\mathrm{NAD}^{+}$as cosubstrate [1]. Sirtuins have been initially classified as class III histone deacetylases (HDACs), indeed SIRT6 has been shown to catalyze the deacetylation of lysines K9, K18, and K56 of histone H3 [2-5]. Nonetheless, SIRT6 promotes different reactions on a wide range of substrates beyond histones [6]. In addition to protein deacetylation, SIRT6 catalyzes the protein deacylation of long-chain fatty acyl groups from the $\varepsilon$-amino groups of lysines and the mono-ADP-ribosylation of lysine and arginine residues of chromatin silencing DNA repair proteins [7]. 
SIRT6 expression is almost ubiquitous, with the highest levels detected in skeletal muscle, heart, brain, liver, kidney, and thymus [8,9]. SIRT6-catalyzed deacetylation is associated with compaction of chromatin and consequent transcriptional repression, as well as response to DNA damage. Notably, recent reports indicated that the SIRT6 deacetylase catalytic activity is 100 to 1000 times lower than that of the most active SIRTs [10]. The deacylase efficiency of SIRT6 has been shown to be higher compared to deacetylation, which can be in turn activated by endogenous ligands such as free fatty acids (FFA) [11,12]. Indeed, in vitro demyristoylation activity is roughly 300 times higher than deacetylation. On the other hand, most of SIRT6 cellular functions described to date are related to its deacetylation activity, rather than deacylation, which has been proven in the case of TNF- $\alpha$ [12] and R-Ras2 [13]. These features, along with the ability of SIRT6 to catalyze mono-ADP-ribosylation, depict a complicated picture of its biological functions and related phenotypes.

The capability of SIRT6 to regulate different molecular pathways is pivotal to maintain cellular homeostasis [6]. Upon DNA damage, an increase of SIRT6 levels determines an improvement of chromatin accessibility recruiting several DNA repair factors, such as 53BP1, BRCA1, and RPA to the breakpoint [14]. SIRT6 modulates double strand break (DSB) repair activating both non-homologous end-joining (NHEJ) and homologous recombination (HR), through the interaction with different proteins involved in these molecular pathways [15]. For instance, under oxidative stress SIRT6 associates with the poly[ADPribose]polymerase PARP1 and catalyzes its mono-ADP-ribosylation, thereby stimulating its activity and resulting in improved DSB repair [16].

SIRT6 is also involved in the base excision repair (BER) process in a PARP1-dependent manner [17] and contributes to genome and telomeres integrity in mammalian cells through the interaction with the DNA glycosylase MYH and the endonuclease APE1 [18]. This is in line with earlier studies indicating the requirement of SIRT6 for genome stability and telomeric maintenance in human cells [19]. Through H3K9 deacetylation at telomeres, SIRT6 facilitates the binding of WRN, the protein that is mutated in Werner syndrome, thus promoting proper telomeric function and metabolism [2,20]. Recent studies also indicated that SIRT6 interacts with telomere repeat binding factor 2 (TRF2), a critical protein for telomere maintenance and DNA damage response, catalyzing its deacetylation, leading to ubiquitination and, consequently, proteolysis [21].

SIRT6 is also able to bind at the $5^{\prime}$-UTR of long interspersed element 1 (L1) retrotransposons. Here, it mono-ADP-ribosylates the nuclear corepressor KAP1, thereby facilitating its interaction with the heterochromatin factor $\mathrm{HP} 1 \alpha$ and ensuring genome stability through L1s packaging into transcriptionally inaccessible heterochromatin [22].

Given the requirement of $\mathrm{NAD}^{+}$for their activity, SIRTs have been regarded as pivotal proteins connecting metabolism to cell physiology [23]. Loss-of-function studies performed in mouse models indicated the crucial roles that SIRT6 plays for organism well-being. Indeed, SIRT6-deficient mice displayed alteration of glycolysis and genomic instability, ultimately leading to premature aging and shortened lifespan [24-26].

SIRT6 also plays an important role in the regulation of inflammatory response, acting both as an activator and as a repressor. For instance, it promotes inflammation through TNF- $\alpha$ demyristoylation at K19 and K20, triggering its secretion by immune cells [12], while acylated TNF- $\alpha$ would be kept and finally degraded in lysosomes. In addition, SIRT6 action determines also upregulation of TNF- $\alpha$ and the pro-inflammatory cytokine IL-8 [27]. Conversely, it blocks the expression of pro-inflammatory factors such as NF- $\mathrm{B}[28,29]$ and IL-6 [30], thereby suppressing the inflammatory mechanisms.

Given its multitasking biological roles in genome maintenance, metabolism, and inflammation, it is not surprising that SIRT6 has a critical role in the regulation of cell fate determination and apoptosis.

One of the main features of tumor cells is their ability to escape from programmed cell death (PCD), proceeding towards unregulated proliferation and consequent malig- 
nant transformation [31]. Due to the role played by SIRT6 in the regulation of cellular homeostasis, mounting evidence points towards its involvement in cancer.

SIRT6 has been found to modulate the expression of both pro- and anti-apoptotic factors, thus influencing cell survival and affecting cancer development in a contextdependent manner. In response to DNA damage, SIRT6 induces apoptosis via mono-ADPribosylation of p53 and p73 in several cancer cells, but not in normal or non-transformed cells [32]. Therefore, SIRT6 shows a dichotomous role in cancer, acting both as tumor promoter and suppressor in a cell context-dependent fashion [33-35]. SIRT6 role in cancer is reminiscent of other sirtuins such as SIRT2, which has been shown to act as either tumor suppressor or promoter in breast cancer, depending on tumor grade [36]. Likewise, SIRT2 may influence sensitivity to chemotherapeutics positively [37] or negatively [38], depending on the cancer type.

Many details connecting the biochemical activity of SIRT6 and the observed phenotypes in both physiological and pathological states are still missing, thus motivating further investigations. Chemical inactivation of SIRT6 through small molecules represents an important way to assess its biological functions. Moreover, the recent discoveries indicating that SIRT6 may also be activated by endogenous ligands encouraged the development of SIRT6 activators. Both activators and inhibitors represent valuable tools to study the functions of this multifaceted enzyme. In addition, they can act as lead compounds for the development of therapeutics for the treatment of diseases such as cancer, diabetes, obesity, and neurodegeneration. Cancer encompasses a vast number of different diseases characterized by a diverse and complex subset of biochemical features. Therefore, depending on the specific type of cancer, SIRT6 activation or inhibition may be beneficial.

In this review, we scrutinize the functions of SIRT6 in the regulation of cell death and cancer. We also focus on the most relevant SIRT6 activators and inhibitors, which may be used as tools to elucidate on SIRT6 physiological and pathological roles and may also represent potential therapeutics for SIRT6-related diseases.

\section{Regulation of SIRT6 Expression and Activity}

Several factors regulate SIRT6 expression and activity at transcriptional and posttranscriptional level, influencing its role on tumor initiation and progression. The transcription factor AP-1 induces transcription of SIRT6 through its c-Fos subunit, which directly binds to SIRT6 promoter. This correlation has been discovered in hepatocellular carcinoma (HCC), whereby c-Fos-mediated SIRT6 transcriptional activation initiates a tumor-suppressor pathway that will be explained in detail in the following section [39]. In contrast, the binding of the transcription factor E2F1 to SIRT6 promoter region blocks SIRT6 transcription under both normoxia and hypoxia conditions [40]. Similarly, PARP1 seems to downregulate SIRT6 expression since treatment with its inhibitor PJ-34 results in augmented levels of SIRT6 mRNA [41].

The expression and activity of SIRT6 is also modulated by the microRNA system. In particular, miR-33a, miR-33b and miR-34a were shown to decrease mRNA and protein levels of SIRT6 in different cell types [42-46]. In addition, SIRT6 and miR-122 negatively regulate their expression in a reciprocal way. miR-122, the most abundant hepatic miRNA, binds to the 3'-UTR of SIRT6 hence reducing its levels, while SIRT6 downregulates miR-122 through H3K56 deacetylation at its promoter [47]. Notably, SIRT6 and miR-122 oppositely modulate the transcription of the same genes involved with metabolism and fatty acid oxidation [47]. Similarly, SIRT6 and miR-125b negatively regulate each other, and miR$125 \mathrm{~b}$ was shown to interact with 3'-UTR of SIRT6, directly suppressing its expression [48]. Finally, miR-766 and SIRT6 were shown to negatively regulate each other in a feedback manner and this mechanism is relevant in the context of aging cells reprogramming [49].

SIRT6 functions are also regulated at a post-translational level, through modifications and key interactions with other proteins (Table 1). For instance, AKT1-mediated phosphorylation of SIRT6 at Ser338 triggers its ubiquitination by MDM2, finally leading to proteasomal degradation [50]. Notably, cyclic AMP (cAMP) decreases SIRT6 levels through 
activation of PKA which in turn mediates the inhibition of the Raf-MEK-ERK pathways, finally leading to SIRT6 ubiquitination. In addition, PKA activates the transcription factor CREB, which in turn decreases SIRT6 expression [51]. On the other hand, the ubiquitin ligase CHIP catalyzes non-canonical SIRT6 ubiquitination at Lys170, thus preventing its canonical ubiquitination and protecting the protein from proteasomal degradation [52]. In addition, SIRT6 was demonstrated to be a substrate of the ubiquitin-specific peptidase USP10 which de-ubiquitinates SIRT6, thereby protecting it from proteasome-dependent degradation [53]. Finally, SIRT6 was found to interact with the SUMO-conjugating enzyme UBC9 which catalyzes its conjugation with SUMO1. SIRT6 SUMOylation positively regulates H3K56 deacetylation but, has no influence on H3K9. This modification promotes SIRT6 binding to c-Myc, and consequent occupancy at c-Myc target genes loci. SIRT6 then deacetylates H3K56Ac in these regions, thereby leading to silencing of c-Myc target genes [54].

Table 1. Main SIRT6 interacting partners, modifications and influence on protein activity.

\begin{tabular}{cccc}
\hline Interactor & Modification & Influence on SIRT6 & Reference \\
\hline AKT1 & Ser338 Phosphorylation & Degradation & {$[50]$} \\
CHIP & Lys170 Ubiquitination & Stabilization & {$[52]$} \\
USP10 & Deubiquitination & Stabilization & {$[53]$} \\
UBC9 & SUMOylation & Increased H3K56 deacetylation & {$[54]$} \\
\hline
\end{tabular}

\section{Role of SIRT6 in Cancer}

Numerous studies aimed at analyzing the pathways that are dysregulated in cancer have been focusing on the characterization of different molecular targets acting on DNA repair and cell death. Through their modulation, it is possible to control three important processes in tumor development such as initiation, progression and metastatization. SIRT6 prevents genome instability, maintains telomere integrity, facilitates DNA repair, and regulates metabolic homeostasis, thereby may have a pivotal role in carcinogenesis [6].

An increasing number of studies reported an altered expression of SIRT6 in cancer, both at gene and protein levels. SIRT6 in tumorigenesis can be considered a doubleedged sword, acting either as tumor promoter or suppressor depending on the biological context (Figure 1), and several reports underlined the connection between its action and the modulation of cell death in cancer [32,55].

\subsection{Tumor Suppression Function}

The analysis of different databases, such as the Cancer Cell Line Encyclopedia [56], reveals that SIRT6 expression is suppressed in several types of cancer, suggesting a tumor suppressor role for this enzyme. In addition, many SIRT6 point mutations able to alter and often impair its biological and enzymatic functions were discovered in tumors, ultimately leading to metabolic changes and transformation [33].

In ovarian cancer tissues, SIRT6 expression levels are lower than in the non-transformed counterparts [57]. Moreover, SIRT6 overexpression in ovarian cancer cells inhibits proliferation and the expression of Notch3, a prognostic factor for ovarian serous carcinoma [58]. A similar effect was observed also in glioma cells in which SIRT6 suppresses the expression of poly $(\mathrm{C})$-binding protein 2 (PCBP2) through H3K9 deacetylation at its promoter, hence blocking tumor cell growth $[59,60]$. Further evidence suggests the tumor suppressor role of SIRT6 in other types of cancer such as hepatocellular carcinoma (HCC) [61], lung cancer [62] and nasopharyngeal carcinoma (NPC) [63], where SIRT6 has been found downregulated at gene level compared to normal tissues. In HepG2 cells, SIRT6 overexpression impairs cancer proliferation through the inhibition of ERK1/2 signaling and promotes apoptosis by inducing increased levels of cleaved caspase-3 [61]. 


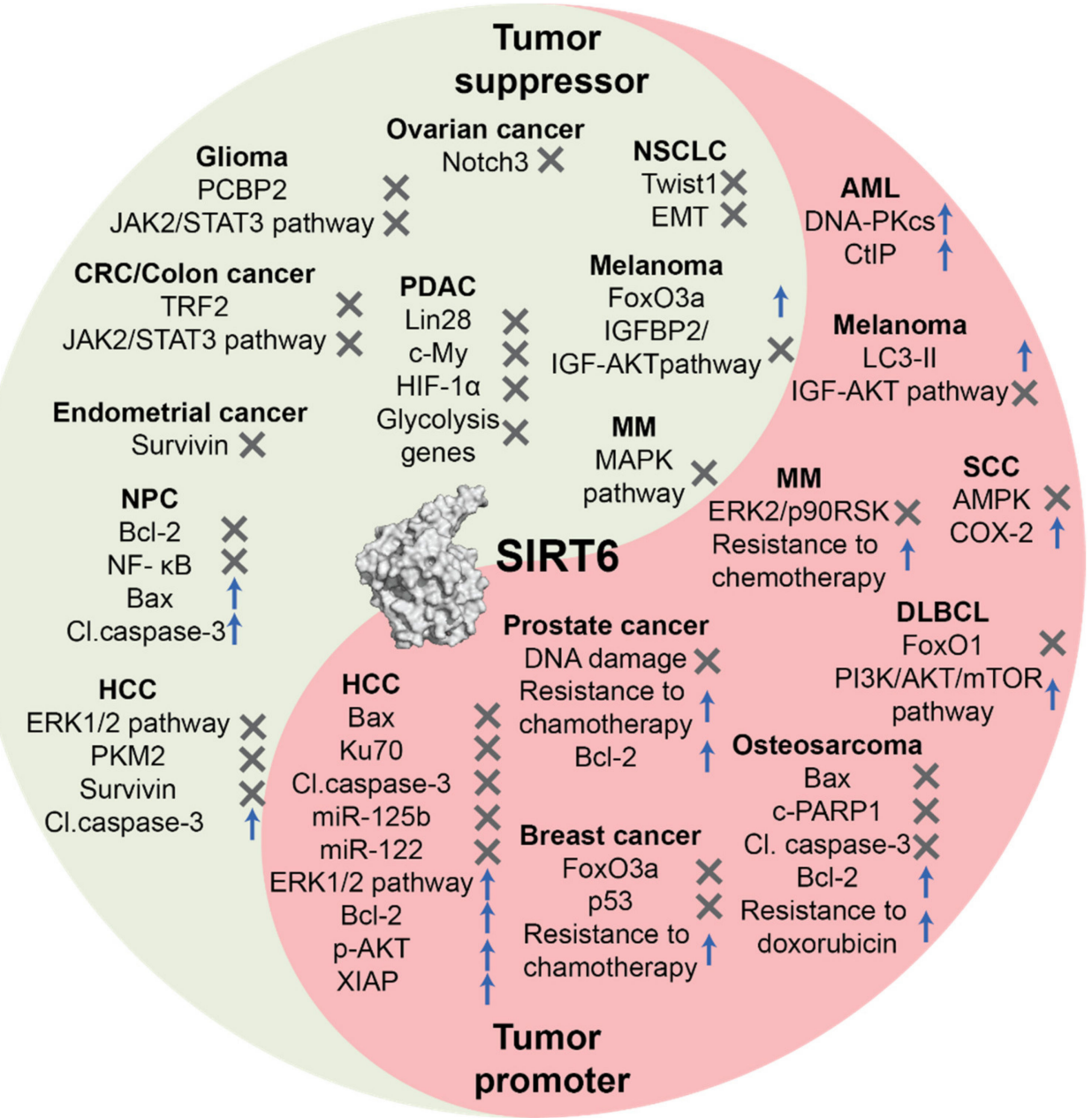

Figure 1. The contrasting functions of SIRT6 in tumorigenesis. SIRT6 acts both as tumor suppressor and tumor promoter in different contexts, depending on tissue types and the stage of cancer. Surface representation of SIRT6 crystal structure was retrieved from the Protein Data Bank (PDB ID: 3ZG6) and rendered with PyMol (Schrödinger).

A negative correlation between SIRT6 and the nuclear glycolytic enzyme pyruvate kinase M2 (PKM2) was discovered in a HCC. PKM2 has non-metabolic oncogenic functions and is directly involved in metastatization. In hepatocellular carcinoma tissues reduced levels of SIRT6 were observed, along with high levels of acetylated PKM2 at residue K433. These findings highlighted a molecular mechanism by which SIRT6 deacetylates PKM2 at K433, triggering its nuclear export and blocking its oncogenic functions [64].

In non-small cell lung cancer (NSCLC), the inhibition of proliferation mediated by SIRT6 is the result of the suppression of Twist1 expression, a key player involved in two different tumor processes such as metastatization and epithelial-mesenchymal transition (EMT) [62]. Lack of SIRT6 in pancreatic ductal adenocarcinoma (PDAC) determines hyperacetylation of $\mathrm{H} 3 \mathrm{~K} 9$ and $\mathrm{H} 3 \mathrm{~K} 56$ at the promoter of the oncogene Lin28b, along with c-Myc recruitment, resulting in the enhancement of cancer progression and metastatization [65]. PDAC is also characterized by increased expression of glycolytic genes which is correlated with SIRT6 downregulation [26]. Indeed, SIRT6 deacetylates H3K9 at glycolytic genes promoters [66] and co-represses the hypoxia-inducible factor $1 \alpha(\mathrm{HIF}-1 \alpha)$. This protein facilitates the expression of glycolytic genes such as lactate dehydrogenase (LDH), pyruvate dehydrogenase kinase-1 (PDK1), phosphofructokinase-1 (PFK1), and the glucose transporter-1 (GLUT1) [66]. Through this action, SIRT6 exerts a tumor suppressor role as it blocks the so-called Warburg effect. This is an alteration in glucose metabolism common in cancer cells in which ATP is produced mainly through glycolysis, even in the presence of oxygen. This leads to quick production of energy to support fast cancer cell growth [67]. 
Colorectal cancer (CRC) is also characterized by SIRT6 downregulation and increased expression of glycolysis-related genes [26]. In addition, SIRT6 and TRF2 expression levels were inversely correlated in a cohort of CRC patients, suggesting a regulatory mechanism whereby SIRT6 induces degradation of TRF2, which is overexpressed during oncogenesis. Nonetheless, the consequences of SIRT6/TRF2 in the damage repair pathway and apoptosis remains to be further clarified [21]. As previously mentioned, the peptidase USP10 deubiquitinates SIRT6, thereby protecting it from proteasomal degradation. In line with this, USP10 expression correlates positively with SIRT6 expression and both proteins are downregulated in colon cancer. Additionally, USP10 blocks tumor formation via p53 and SIRT6-mediated degradation of c-Myc, thereby stopping cell cycle progression and cancer cell growth [53]. It is well known that JAK2/STAT3 signaling pathway is constitutively activated in most primary malignant cancers and its activation rate is positively related with tumor grade. A recent study showed that high levels of SIRT6 expression in colon cancer are associated with a better prognosis. Indeed, following the action of the non-coding RNA miRNA-34c-5p, JAK2/STAT3 pathway is activated, thereby negatively regulating SIRT6, inhibiting apoptosis, and inducing colon cancer growth [68]. As mentioned above, SIRT6 protein expression is reduced in glioma cell lines, where it negatively correlates with the expression of miR-33a. In this cancer model, SIRT6 restoration led to apoptosis through upregulation of Bax and cleaved caspase-8, along with downregulation of Bcl-2 and inhibition of the JAK2/STAT3 pathway. These events resulted in the reduction of glioma cancer cell survival [44].

In NPC, the NF- $K B$ pathway is particularly active and is involved in the activation of anti-apoptotic proteins such as FLIP, c-IAP1/2 and XIAP, favoring cancer resistance and progression [69]. Notably, SIRT6 was found to be downregulated in NPC and its restoration led to decreased levels of NF- $\mathrm{kB}$ and anti-apoptotic factor Bcl-2, along with augmented expression of pro-apoptosis mediators Bax (Bcl-2 associated $\mathrm{X}$ protein) and cleaved caspase-3 [63].

Mounting evidence points towards a functional correlation between the activities of SIRT6 and the anti-apoptosis factors. In several cancer types, low levels of SIRT6 were associated with marked expression of the pro-survival protein survivin, a condition that correlates with tumor aggression and poor patient survival [39,70]. In a liver cancer mouse model SIRT6 has a tumor suppression effect, repressing the transcription of survivin at two levels: through H3K9 deacetylation at its promoter and through NF-kB deacetylation, which impairs its binding to survivin promoter [39]. The same molecular mechanism has also been described in endometrial cancer cell lines [70], thus highlighting the pro-apoptotic role of SIRT6 via survivin inhibition.

In melanoma, SIRT6 has been shown to act as both a tumor suppressor and promoter. A recent investigation indicated that SIRT6 expression is positively correlated with FoxO3a expression [71]. FoxO3a is a tumor suppressor [72] involved in the positive regulation of apoptosis [73-75], in the protection against oxidative stress [76], and also in the cholesterol biosynthesis regulation along with SIRT6 [77,78]. In addition, FoxO3a negatively regulates the expression aerobic glycolytic genes. SIRT6 overexpression was shown to augment FoxO3a levels, reducing the levels of glycolytic genes and cancer cell proliferation [71]. SIRT6 activity also influences the IGF-AKT pathway. Strub et al. showed that SIRT6 downregulation increases H3K56 acetylation at the promoter of Insulin-like Growth Factor Binding Protein 2 (IGFBP2), thereby increasing its expression levels. IGFBP2 then activates the Insulin Growth Factor 1 receptor (IGF-1R) and downstream signaling of the antiapoptotic protein $\mathrm{AKT}$ (or protein kinase $\mathrm{B}, \mathrm{PKB}$ ), thus promoting melanoma cell survival and drug resistance to MAPK signaling inhibitors [79].

\subsection{Tumor Promoter Function}

An increasing number of studies report that SIRT6 expression is significantly associated with both solid and hematological human cancer types such as head and neck squamous cell carcinoma [80], HCC [55,81-83], prostate cancer [84], breast cancer [85], 
skin squamous cell carcinoma (SCC) [45,86], melanoma [87-90], diffuse large B-cell lymphoma (DLBCL) [91], and acute myeloid leukemia (AML) [92] highlighting its role in tumorigenesis as tumor promoter.

SIRT6 oncogenic role was extensively studied in HCC, where it was found to be upregulated in a subset of HCC tissue and cell lines. Its high expression levels were associated with increased tumor grade and metastatization $[81,82]$. Indeed, it facilitates the EMT, which is one of the main processes involved in metastasis. This outcome is obtained through deacetylation of Beclin-1, triggering autophagic degradation of E-cadherin, a pivotal cell adhesion protein [81]. In another study performed on HCC tissues, SIRT6 was shown to deacetylate $\mathrm{H} 3 \mathrm{~K} 9$ at the promoter of the apoptotic activator Bax, resulting in evasion from apoptosis [82]. Conversely, SIRT6 depletion determined hyperacetylation of Bax promoter, with the recruitment of several transcription factors (e.g., p53) that in turn activate Bax and its downstream effectors [93], resulting in an activation of death pathway. Moreover, mRNA levels of SIRT6 and Bax were negatively correlated in human samples. These results were corroborated by experiments performed in mouse xenografts, where SIRT6 knockout impaired tumor growth and led to apoptosis [82]. It has also been reported that the inhibition of the molecular pathway of Bax is the result of the association between SIRT6 and Ku70, a subunit of the complex involved in DNA repair [94]. Although SIRT6 is a nuclear protein, during cell cycle progression it can translocate to the cytosol and catalyze Ku70 deacetylation, consequently blocking Bax-mediated intrinsic apoptotic pathway [94]. Novel insights about the oncogenic role of SIRT6 in HCC indicated that the SIRT6-mediated activation of the ERK1/2 pathway can promote cancer cell proliferation and invasion. In addition, SIRT6 overexpression induces upregulation of Bcl-2, while downregulates Bax and cleaved caspase-3, consequently inhibiting the intrinsic apoptotic pathway [55]. Moreover, SIRT6 deacetylates the anti-apoptotic factor AKT, which in turn promotes its phosphorylation and increases its activity. AKT then phosphorylates $\mathrm{X}$-linked inhibitor of apoptosis protein (XIAP) thereby inducing evasion from apoptosis and cancer cell proliferation [83]. Furthermore, the oncogenic role of SIRT6 in HCC was also elucidated by studying the relations with miRNA levels. Indeed, a high expression of SIRT6 is associated with low levels of miR-125b with consequent inhibition of the apoptotic pathway [48]. The previously mentioned reciprocal regulation between SIRT6 and miR-122 has been described as a crucial mechanism to control hepatic metabolic functions. Intriguingly, the loss of this reciprocal negative regulation in HCC patients, followed by high expression of both players, correlates with hepatic good prognosis, suggesting that these two factors may serve as biomarkers for HCC prognosis [47].

The tumor promoting role of SIRT6 has also been investigated in other cancer types, where reduction of SIRT6 levels is associated to a better response to chemotherapeutics $[84,85,95]$. In metastatic prostate cancer cell lines, SIRT6 knockdown improves chemotherapy sensitivity, with increased DNA damage and consequent cell cycle arrest in G1 along with Bcl-2 downregulation and apoptosis induction [84]. In breast cancer cells, high levels of SIRT6 are associated with resistance to epirubicin and paclitaxel. Indeed, SIRT6 activates DNA repair pathways in response to epirubicin-induced damage. SIRT6 also antagonizes the activity of the tumor suppressors p53 and FoxO3a both directly via deacetylation, and indirectly through suppression of their expression [85]. In osteosarcoma cell lines, SIRT6 knock-down has been shown to potentiate the effect of conventional chemotherapeutics inducing block of cancer cell proliferation and cell death [95]. SIRT6 inhibition, together with the action of doxorubicin, results in an increase of apoptotic response with a higher expression of Bax and cleaved forms of PARP1 and caspase-3, along with the downregulation of Bcl2 [95].

The tumor promoting capacity of SIRT6 has also been demonstrated in skin SCC, where SIRT6 is upregulated [86]. Following exposure to UV-B radiation, the activation of AKT pathway induces an increase of SIRT6 levels which promotes COX-2 expression through repression of AMP-activated protein kinase (AMPK) signaling, finally leading to cancer cell survival and proliferation [86]. In addition, SIRT6 is silenced by miR-34a, 
a miRNA critical for squamous cell differentiation which is suppressed in skin and oral SCCs. Notably, SIRT6 downregulation is sufficient to reactivate the pro-differentiation effects of miR-34a and to reduce the cell proliferation potential [45].

As mentioned above, SIRT6 has also tumor promoting functions in melanoma. Indeed, it was shown to be upregulated in both cell lines and clinical tissue samples of human melanoma, and its knockdown resulted in cell cycle arrest at G1, senescence and impairment of cell growth [87]. In addition, SIRT6 was found to positively modulate autophagy as its knockdown was associated with decreased conversion of the microtubuleassociated protein 1A/1B-light chain 3 (LC3) from LC3-I to the phosphatidylethanolamineconjugated form LC3-II, a crucial autophagosome initiator [87]. In agreement with this, a CRISPR/Cas9-mediated knockout of SIRT6 determined antiproliferative effects both in vitro and in vivo [88]. Notably, another study indicated that SIRT6 has a dichotomous effect in melanoma, suppressing the growth of primary melanoma while promoting the development of metastatic melanoma both in vitro and in vivo. This action was shown to be correlated with the expression of autophagy biomarkers, suggesting an autophagydependent mechanism played by SIRT6. As previously mentioned, SIRT6 inhibits the IGF-AKT pathway, which is also responsible for autophagy suppression [89]. Mechanistically, autophagy aids the degradation of toxic protein at initial stages, but also reduces cancer cell susceptibility to stress and promotes the development of established tumors, hence explaining SIRT6 dual role in melanoma [90].

SIRT6 was found to be overexpressed also in DLBCL where its levels are related to poor prognosis. In this setting, SIRT6 activates the PI3K/AKT/mTOR pathway, thus facilitating cancer progression [91]. Moreover, SIRT6 inhibition or knockdown result in reduced drug resistance and apoptotic cell death induction [91]. Indeed, in LY1 and LY8 follicular lymphoma cells, SIRT6 knockdown promotes the apoptotic cascade with high levels of cleaved PARP and reduction of several phosphorylated targets of PI3K pathway such as PI3K(p110), Akt (Ser473), and p-mTOR, and a significant increase of the FoxO1 oncosuppressor levels [91].

SIRT6 is also upregulated in AML if compared with normal CD34+ hematopoietic progenitors [92]. Following genotoxic stress, SIRT6 is recruited to DNA damage sites where it activates through deacetylation DNA-PKcs and CtIP, constitutively acetylated in AML cells, consequently promoting DNA repair which in turn supports cancer cell survival. Conversely, the overexpression of SIRT6 catalytic mutant (H133Y) in AML determines more pronounced anticancer effects [92]. SIRT6 is also highly expressed in MM cells, in which it is associated with adverse prognosis [96]. However, in this case, the authors propose that SIRT6 higher expression is an adaptive response to genomic instability and describe a situation where SIRT6 exerts a dual role. Indeed, SIRT6 interacts with the transcriptional activator ELK1 and deacetylates H3K9 at the promoters of ERK signaling-related genes, thus downregulating the expression of mitogen-activated protein kinase (MAPK) pathway genes and inhibiting proliferation consistent with a role as tumor suppressor, rather than promoter. In line with this, its depletion in MM xenografts enhances cancer growth. On the other hand, SIRT6 knockdown increased ERK2 expression and p90RSK phosphorylation thus facilitating DNA repair and, consequently, resistance to DNA damaging agents. In line with this, low SIRT6 levels sensitise MM xenografts to DNA-damaging agents such as doxorubicin [96]. This study provides important insights into the crosstalk between SIRT6 activity and cancer cell proliferation. Indeed, whilst showing a tumor-suppressor role in this type of cancer, the authors suggest that SIRT6 inhibition may enhance sensitivity to chemotherapeutics consequently improving patient prognosis.

A summary of SIRT6 role in cancer regulation is provided in Table 2. 
Table 2. Expression of SIRT6 in cancer and related biological functions.

\begin{tabular}{|c|c|c|c|}
\hline Cancer Type & SIRT6 Expression & Cell Death Pathways and Regulators & Reference(s) \\
\hline Ovarian cancer & Downregulated & SIRT6 inhibits Notch3 expression and cell proliferation. & [57] \\
\hline Glioma & Downregulated & $\begin{array}{l}\text { SIRT6 suppresses PCBP2 expression and cell proliferation. } \\
\text { SIRT6 inhibits JAK2/STAT3 pathway and reduces cell survival. }\end{array}$ & $\begin{array}{l}{[59]} \\
{[44]}\end{array}$ \\
\hline $\begin{array}{l}\text { Non-Small Cell Lung Cancer } \\
\text { (NSCLC) }\end{array}$ & Downregulated & $\begin{array}{l}\text { SIRT6 inhibits Twist-1 expression suppressing metastatization and } \\
\text { EMT. }\end{array}$ & [62] \\
\hline $\begin{array}{c}\text { Pancreatic Ductal } \\
\text { Adenocarcinoma (PDAC) }\end{array}$ & Downregulated & $\begin{array}{l}\text { SIRT6 inhibits Lin28b expression and c-Myc recruitment } \\
\text { suppressing cancer progression and metastatization. }\end{array}$ & [65] \\
\hline $\begin{array}{l}\text { Colorectal cancer } \\
\text { (CRC)/Colon cancer }\end{array}$ & Downregulated & $\begin{array}{l}\text { SIRT6-mediated deacetylation induces TRF2 ubiquitination, } \\
\text { leading to proteasomal degradation } \\
\text { USP10 inhibits SIRT6 degradation and blocks tumor growth via } \\
\text { p53 and SIRT6-mediated degradation of c-Myc. } \\
\text { miRNA-34c-5p inhibits SIRT6 expression and activates } \\
\text { JAK2/STAT3 pathway inhibiting apoptosis. }\end{array}$ & $\begin{array}{l}{[21]} \\
{[53]} \\
{[68]}\end{array}$ \\
\hline $\begin{array}{l}\text { Nasopharyngeal Carcinoma } \\
\text { (NPC) }\end{array}$ & Downregulated & $\begin{array}{l}\text { SIRT6 downregulates Bcl-2 and NF- } \mathrm{KB} \text { and induces apoptosis } \\
\text { mediated through upregulation of Bax and cleaved caspase- } 3 \text {. }\end{array}$ & [63] \\
\hline Endometrial cancer & Downregulated & SIRT6 inhibits survivin expression promoting apoptosis & [70] \\
\hline Melanoma & Downregulated & $\begin{array}{l}\text { SIRT6 increases FoxO3a expression levels } \\
\text { SIRT6 downregulates IGFBP2 through, thus impairing the } \\
\text { activation of IGF-1R and AKT pathway, responsible of cancer cell } \\
\text { survival and drug resistance. } \\
\text { SIRT6-mediated suppression of IGF-AKT signaling stimulates } \\
\text { autophagy, a tumor protective factor only at early stages. }\end{array}$ & $\begin{array}{l}{[71]} \\
{[79]} \\
{[89]}\end{array}$ \\
\hline $\begin{array}{l}\text { Hepatocellular Carcinoma } \\
\qquad(\mathrm{HCC})\end{array}$ & Downregulated & $\begin{array}{l}\text { SIRT6 induces apoptosis via upregulation of cleaved caspase-3 } \\
\text { and ERK1/2 pathway inhibition. } \\
\text { SIRT6 deacetylates PKM2 inducing its nuclear export and blocks } \\
\text { metastatization. } \\
\text { SIRT6 inhibits survivin expression and induces apoptosis. }\end{array}$ & $\begin{array}{l}{[61]} \\
{[64]} \\
{[39]}\end{array}$ \\
\hline $\begin{array}{l}\text { Hepatocellular Carcinoma } \\
\qquad(\mathrm{HCC})\end{array}$ & Upregulated & $\begin{array}{l}\text { SIRT6 downregulates Bax and blocks apoptosis. } \\
\text { SIRT6 deacetylates Ku70 and blocks Bax-mediated apoptosis. } \\
\text { SIRT6 promotes proliferation and invasion inducing ERK1/2 } \\
\text { pathway and Bcl-2 expression and downregulating Bax and } \\
\text { cleaved caspase-3. } \\
\text { SIRT6 promotes proliferation and cell death evasion increasing } \\
\text { p-AKT levels and XIAP expression. } \\
\text { SIRT6 inhibits miR-125b expression and apoptosis. } \\
\text { Reciprocal regulation between SIRT6 and miR-122 correlates with } \\
\text { tumor progression. }\end{array}$ & $\begin{array}{l}{[82]} \\
{[94]} \\
{[55]} \\
{[83]} \\
{[48]} \\
{[47]}\end{array}$ \\
\hline Prostate cancer & Upregulated & $\begin{array}{l}\text { SIRT6 knockdown increases sensitivity to chemotherapy, } \\
\text { DNA damage, cell cycle arrest in G1, Bcl-2 downregulation and } \\
\text { apoptosis induction. }\end{array}$ & [84] \\
\hline Breast cancer & Upregulated & $\begin{array}{l}\text { SIRT6 increases resistance to epirubicin and paclitaxel and } \\
\text { negatively modulates the acetylation status and expression of } \\
\text { FoxO3a and p53. }\end{array}$ & [85] \\
\hline Osteosarcoma & Upregulated & $\begin{array}{l}\text { SIRT6 facilitates DNA repair in cancer cells, leading to } \\
\text { doxorubicin resistance. SIRT6 also inhibits the expression of Bax, } \\
\text { cleaved-PARP1 and cleaved-caspase3 and increases Bcl-2 } \\
\text { expression leading to apoptosis evasion. }\end{array}$ & [95] \\
\hline $\begin{array}{l}\text { Squamous Cell Carcinoma } \\
\text { (SCC) }\end{array}$ & Upregulated & $\begin{array}{l}\text { Under UVB radiation, AKT induces SIRT6 expression that } \\
\text { promotes COX-2 action and AMP-activated protein kinase } \\
\text { (AMPK) repression leading to cell survival and proliferation. } \\
\text { SIRT6 is silenced by miR-34a and its downregulation induces cell } \\
\text { differentiation and reduces cancer cell proliferation potential }\end{array}$ & $\begin{array}{l}{[86]} \\
{[45]}\end{array}$ \\
\hline Melanoma & Upregulated & $\begin{array}{l}\text { SIRT6 activity increases the levels of the } \\
\text { phosphatidylethanolamine-conjugated protein LC3-II, a crucial } \\
\text { autophagosome initiator. } \\
\text { SIRT6 suppresses IGF-AKT signaling, thus stimulating autophagy } \\
\text { which is a protective factor at early stages, but promotes tumor } \\
\text { development at later stages. }\end{array}$ & [87] \\
\hline $\begin{array}{l}\text { Diffuse Large B-Cell } \\
\text { Lymphoma (DLBCL) }\end{array}$ & Upregulated & $\begin{array}{l}\text { SIRT6 activates PI3K/AKT/mTOR pathway, thus promoting } \\
\text { cancer proliferation. } \\
\text { SIRT6 knockdown determines upregulation of the oncosuppressor } \\
\text { FoxO1. }\end{array}$ & [91] \\
\hline $\begin{array}{l}\text { Acute Myeloid Leukemia } \\
\text { (AML) }\end{array}$ & Upregulated & $\begin{array}{l}\text { SIRT6 increases cell death resistance via DNA-PKcs and } \\
\text { CtIP deacetylation. }\end{array}$ & [92] \\
\hline Multiple Myeloma (MM) & Upregulated & $\begin{array}{l}\text { SIRT6 downregulates MAPK pathway genes suppressing } \\
\text { cell proliferation. } \\
\text { SIRT6 increases resistance to DNA-damaging agents through } \\
\text { inhibition of ERK2/p90RSK signaling. }\end{array}$ & [96] \\
\hline
\end{tabular}




\section{Pharmacological Modulation of SIRT6}

The discovery that SIRT6 deacetylase activity is enhanced by FFA, along with its positive role in aging and cell metabolism stimulated research groups towards the development of SIRT6 activators. Conversely, the dual role of SIRT6 in cancer, cell survival and inflammation has also motivated the development of SIRT6 inhibitors.

The possibility of either activating or inhibiting SIRT6 in a context-dependent manner paves the way for personalized pharmacology. From a wider perspective, highly potent and selective SIRT6 modulators (both activators and inhibitors) allow to better scrutinize the molecular details of its activity, and further validate this complex enzyme as a potential pharmacological target.

In the following sections, we discuss the most relevant SIRT6 activators and inhibitors that have been indicated to impact cancer progression and cell death so far.

\subsection{SIRT6 Activators}

To give a benchmark for the evaluation of SIRT6 activators (Table 3), it is worth mentioning the initial reports describing FFA-mediated SIRT6 activation. Myristic acid (1a), a 14-carbons fatty acid, increased SIRT6 deacetylase activity up to 10.8 times, with an $\mathrm{EC}_{50}$ (concentration able to induce $50 \%$ of maximal activation) of $246 \mu \mathrm{M}$ and a 35-fold maximum increase in catalytic efficiency $\left(k_{c a t} / K_{m}\right)$, indicating enhanced affinity of SIRT6 for its substrate [11]. The unsaturated 18-carbons FFAs oleic (1b) and linoleic acid (1c) (Figure 2) displayed $\mathrm{EC}_{50}$ values of $90 \mu \mathrm{M}$ and $100 \mu \mathrm{M}$, yielding up to 5.8 and 6.8 times SIRT6 maximum activation, respectively [11]. Intriguingly, the ethanolamine derivatives of myristic acid and oleic acid, myristoylethanolamide (MEA, 2a) and oleoylethanolamide (OEA, 2b) showed up 2-fold SIRT6 activation and $\mathrm{EC}_{50}$ values of $7.5 \mu \mathrm{M}$ and $3.1 \mu \mathrm{M}$, respectively [97].

Table 3. Most relevant SIRT6 activators.

\begin{tabular}{|c|c|c|c|c|}
\hline Compound & Structure & Effect on SIRT6 Activity & Cellular and In Vivo Effects & Reference(s) \\
\hline $\begin{array}{c}\text { 3c } \\
\text { Cyanidin }\end{array}$ & & $\begin{array}{c}\mathrm{EC}_{50}=460 \mu \mathrm{M} \\
\times 55 \text { max activation } \\
\quad(\text { deacetylation) }\end{array}$ & $\begin{array}{l}\text { In Caco-2 cells: } \\
\text { dose-dependent SIRT6 } \\
\text { upregulation; increased } \\
\text { expression of FoxO3 } \alpha . \\
\text { Decreased expression of Twist1 } \\
\text { and GLUT1. }\end{array}$ & [98] \\
\hline $\begin{array}{c}\mathbf{4} \\
\text { UBCS039 }\end{array}$ & & $\begin{array}{c}\mathrm{EC}_{50}=38 \mu \mathrm{M} \\
\times 3.5 \text { max activation } \\
(\text { deacetylation })\end{array}$ & $\begin{array}{l}\text { SIRT6 activation in NSCLC, } \\
\text { colon, epithelial cervix } \\
\text { carcinoma, and fibrosarcoma. } \\
\text { Decrease of H3K9 and H3K56 } \\
\text { acetylation and } \\
\text { autophagy-related cell death. }\end{array}$ & {$[99,100]$} \\
\hline $\begin{array}{c}5 \mathbf{a} \\
\text { MDL-800 }\end{array}$ & & $\begin{array}{c}\mathrm{EC}_{50}=10.3 \mu \mathrm{M} \\
\times 22 \text { max activation } \\
\quad(\text { deacetylation) }\end{array}$ & $\begin{array}{l}\text { Dose-dependent decrease of } \\
\text { H3K9Ac and H3K56Ac in HCC } \\
\text { and NSCLC causing cell cycle } \\
\text { arrest. HCC tumor growth } \\
\text { suppressed also in mouse } \\
\text { xenograft models. }\end{array}$ & {$[101,102]$} \\
\hline $\begin{array}{c}\text { 5c } \\
\text { MDL-811 }\end{array}$ & & $\begin{array}{r}\mathrm{EC}_{50}=5.7 \mu \mathrm{M} \\
\text { (deacetylation) }\end{array}$ & $\begin{array}{l}\text { Dose-dependent reduction of } \\
\text { H3K9Ac, H3K18Ac, } \\
\text { and H3K56Ac levels in } \\
\text { different CRC cell lines and } \\
\text { antiproliferative effects } \\
\text { associated with marked G0/G1 } \\
\text { cell cycle arrest. CRC growth } \\
\text { suppressed in patient-derived } \\
\text { organoids and anti-tumor } \\
\text { efficacy in cell line-derived and } \\
\text { patient-derived xenografts. }\end{array}$ & [103] \\
\hline
\end{tabular}


Table 3. Cont.

\begin{tabular}{|c|c|c|c|c|}
\hline Compound & Structure & Effect on SIRT6 Activity & Cellular and In Vivo Effects & Reference(s) \\
\hline 6 & & $\begin{array}{c}\mathrm{EC}_{50}=5.35 \mu \mathrm{M} \\
\text { (deacetylation) } \\
\mathrm{EC}_{50}=8.91 \mu \mathrm{M} \\
\text { (demyristoylation) }\end{array}$ & $\begin{array}{l}\text { Suppression of PDAC cells } \\
\text { proliferation cell cycle arrest in } \\
\text { G2. Anti-tumor activity in a } \\
\text { human pancreatic tumor } \\
\text { xenograft mouse model } \\
\text { associated with decrease of } \\
\text { H3K9 acetylation levels. }\end{array}$ & [104] \\
\hline
\end{tabular}<smiles>[R]C(=O)CCCCCCC/C=C\CCCCCCCC</smiles>

Figure 2. Free fatty acid SIRT6 activators and derivatives.

Early studies on flavonoids indicated that the natural products luteolin (3a) and quercetin (3b) (Figure 3) presented a dual effect on SIRT6 activity. At low concentrations, they acted as inhibitors $\left(\mathrm{IC}_{50}(3 \mathbf{a})=1.9 \mu \mathrm{M} ; \mathrm{IC}_{50}(3 \mathbf{b})=24 \mu \mathrm{M}\right)$. Conversely, at high concentrations they enhanced SIRT6 deacetylase activity, with a 6-fold maximum activation and $\mathrm{EC}_{50}$ value of $270 \mu \mathrm{M}$ in the case of luteolin, and a 10-fold maximum activation and $\mathrm{EC}_{50}$ value of $990 \mu \mathrm{M}$ in the case of quercetin [97]. It should be noticed that the polyphenol structure of these molecules makes them amenable for multi-target interactions and promiscuous activities. Interestingly, the anthocyanidin cyanidin (3c), which showed 55-fold activation of SIRT6 activity and $\mathrm{EC}_{50}=460 \mu \mathrm{M}$, increased also SIRT6 expression levels in a dosedependent fashion and exhibited important effects in colon adenocarcinoma Caco-2 cells. Indeed, it modulated the expression of SIRT6-associated genes with a dose-dependent increase of FoxO3a expression and decrease of Twist1 and GLUT1 levels [98].<smiles>[R]c1c(-c2ccc(O)c(O)c2)oc2cc(O)cc(O)c2c1=O</smiles>

3a Luteolin $\mathrm{R}=\mathrm{H}$;

3b Quercetin $\mathrm{R}=\mathrm{OH}$<smiles>Oc1cc(O)c2cc(O)c(-c3ccc(O)c(O)c3)[o+]c2c1</smiles>

3c Cyanidin

Figure 3. Flavonoid-based SIRT6 modulators.

Crystal structures of SIRT6 in complex with quercetin and cyanidin (PDB IDs: 6QCD and $6 \mathrm{QCH}$, respectively) indicate that these molecules share the same binding at the distal end of acyl binding hydrophobic pocket, with weak interactions with the loop that lids the channel and key hydrogen bonds with Pro62 and conserved water molecules [105].

The first synthetic SIRT6 activator reported in literature was the compound UBCS039 (4) (Figure 4), which exhibited an $\mathrm{EC}_{50}$ of $38 \mu \mathrm{M}$ and 3.5-fold maximum activation of SIRT6 deacetylase activity [99]. Notably, UBCS039 specifically binds to SIRT6, has no significant influence on SIRT1-2-3 deacetylation activities, while stimulates up to 2-fold the SIRT5mediated desuccinylation, which is the physiologically dominant activity of this enzyme. The UBCS039-SIRT6 co-crystal (PDB ID: 5MF6) indicates that UBCS039 shares a similar 
binding site with quercetin and cyanidin at the edge of the acyl channel pocket. Further comparison with the SIRT6-Myr-H3K9 peptide co-crystal reveals that UBCS039 overlaps with the last seven carbons of the acyl chain, in line with experimental evidence suggesting competition for the same binding site, although the affinity of the myristoylated peptide is much higher. Evaluation on histones extracted from calf thymus and HeLa nucleosomes also indicated the stimulation of H3K18 deacetylation by UBCS039 [99]. Cell-based studies revealed that UBCS039 activates SIRT6 and decreased H3K9 and H3K56 acetylation levels in various cancer cell lines such as NSCLC, fibrosarcoma, colon and epithelial cervix carcinoma [100]. In NSCLC and epithelial cervix carcinoma cell lines, UBCS039-mediated SIRT6 activation led to time-dependent autophagosome accumulation and autophagy activation. Cell growth inhibition and apoptosis induction was also observed, indicating an autophagy-associated cell death mechanism. In addition, UBCS039 promoted the accumulation of reactive oxygen species (ROS), in line with a recent study suggesting an important role of SIRT6 in oxygen consumption and consequent ATP production [106]. This study indicates that excessive autophagy stimulation is lethal for cancer cells and paves the way for therapies based on pharmacological activation of SIRT6 to exploit this mechanism [100].

Another synthetic molecule showing efficacy towards SIRT6-mediated pathways in cells is MDL-800 (5a) (Figure 4) [101]. With its $\mathrm{EC}_{50}$ value of $10.3 \mu \mathrm{M}$ and 22-fold maximum SIRT6 deacetylase activity activation, MDL-800 is one of the most potent activators discovered so far. MDL-800 displayed selective activation towards SIRT6, when compared with 18 diverse HDAC family members and decreased H3K9 and H3K56 acetylation in HeLa-extracted nucleosomes. MDL-801 (5b) is the carboxylic acid derivative of MDL-800, it has a slightly better SIRT6 activating potency $\left(\mathrm{EC}_{50}=5.7 \mu \mathrm{M}\right)$ but is not cell permeable. Zhang and colleagues solved the co-crystal structure of SIRT6 bound to ADP-ribose, H3K9 myristoylated peptide, and $\mathbf{5 b}$. Given the structural similarities between MDL-801 and MDL-800, the observed features are likely shared between the two compounds. MDL-801 interacts in a different pocket compared to UBCS039 as it fits in a surface-exposed region of the hydrophobic channel, distal to UBCS039 binding site [101]. At cellular level, MDL800 caused decreased acetylation of H3K9 and H3K56 in three different HCC cell lines. This phenotype is the result of SIRT6 activation and finally led to inhibition of proliferation and cell cycle arrest, with $\mathrm{IC}_{50}$ values for cell growth ( $\mathrm{IC}_{50 \text {-growth }}$ ) between $18.6 \mu \mathrm{M}$ and $24 \mu \mathrm{M}$, depending on the specific cell line. These results were corroborated by experiments in mouse xenograft models, where MDL-800 suppressed HCC tumor growth through SIRT6 activation. A recent investigation expanded these results and showed that MDL-800 inhibits the proliferation of 12 NSCLC cell lines. Cell cycle arrest at the $G_{0} / G_{1}$ phase was observed in NSCLC HCC827 and PC9 cells, consistent with studies indicating the role of SIRT6 in cell cycle regulation [3,53]. Notably, it exhibited synergistic activity with epidermal growth factor receptor tyrosine kinase inhibitors (EGFR-TKIs) in osimertinibresistant HCC 827 and PC9 cells and in patient-derived primary tumor cells. Moreover, MDL-800 suppressed tumor growth in HCC 827 cell-derived xenograft nude mice and caused H3 deacetylation and downregulation of p-MEK and p-ERK in tumor tissues [102]. When tested in old murine-derived induced pluripotent stem cells (iPSCs), MDL-800 improved genome integrity through the activation of both NHEJ and BER, in line with the SIRT6 pivotal role in controlling DNA repair pathways [107]. In addition, it improved the differentiation potential of iPSCs, consistently with the SIRT6 role in the modulation of both iPSCs and ESCs [108,109]. 
<smiles>c1cncc(C2Nc3ccccc3-n3cccc32)c1</smiles>

4 UBCS039<smiles>[R]c1cc(NS(=O)(=O)c2cc(Cl)cc(Cl)c2)ccc1S(=O)(=O)Nc1cc(Br)c(F)cc1C</smiles>

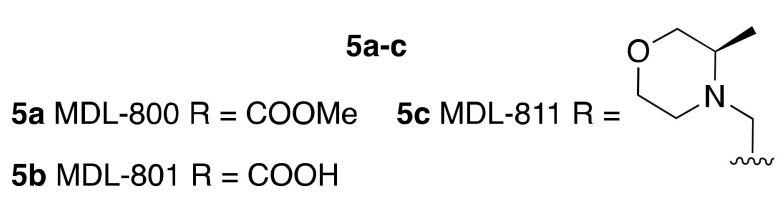

Figure 4. Synthetic SIRT6 activators.<smiles>O=C(NC(c1ccccc1)c1ccccc1)c1cc(-c2cc3ccccc3o2)nc2ccccc12</smiles>

Optimization of MDL-800 led to compound MDL-811 (5c) with improved activity $\left(\mathrm{EC}_{50}=5.7 \mu \mathrm{M}\right)$ and bioavailability in C57BL $/ 6 \mathrm{~J}$ mice (F\%MDL-800 $=71.33 \%$ vs. F\% ${ }_{\text {MDL- } 811}$ $=92.96 \%$ ) [103]. Like its lead compound, MDL-811 is specific towards SIRT6 deacetylase activity and reduced the acetylation levels of $\mathrm{H} 3 \mathrm{~K} 9, \mathrm{H} 3 \mathrm{~K} 18$, and $\mathrm{H} 3 \mathrm{~K} 56$ in nucleosomes extracted from HeLa cells and in HEK293T cells. When evaluated in CRC cell lines, a type of tumor characterized by heavy downregulation of SIRT6, MDL-811 caused a dose-dependent decrease of H3K9Ac, H3K18Ac, and H3K56Ac levels and antiproliferative effects associated with marked G0/G1 cell cycle arrest. MDL-811 also suppressed CRC growth in patient-derived organoids and showed anti-tumor efficacy in cell line-derived and patientderived xenograft models, as well as in a spontaneous CRC mouse model [103]. Mechanistically, the cytochrome P450 family member CYP24A1, that is aberrantly overexpressed in CRC [110,111], was identified as a new target gene of SIRT6. MDL-811 suppressed CRC proliferation synergistically with vitamin $\mathrm{D}_{3}$, which is both a substrate and transcriptional regulator of CYP24A1 and had previously shown anti-tumor efficacy in CRC [112,113]. These features depict MDL-811 as a potential good candidate for clinical studies.

A virtual screening campaign led to the discovery of the compound 6 (Figure 4) as a potent and selective small molecule activator of SIRT6 [104]. This molecule was optimized starting from an initial hit identified using the SIRT6-UBCS039 complex (PDB ID: 5MF6) as model [99]. Compound 6 enhanced both SIRT6 deacetylase and deacylase activities, with $\mathrm{EC}_{50}$ values of $5.35 \mu \mathrm{M}$ and $8.91 \mu \mathrm{M}$ for deacetylation and demyristoylation, respectively. The isoform selectivity was tested over HDAC1-11 and SIRT1-3 showing no activity towards any of these enzymes. According to docking experiments compound 6 binds SIRT6 more towards the distal end of the hydrophobic channel compared to UBCS039, which may justify its augmentation of SIRT6 deacylase activity. Compound 6 suppressed the proliferation of pancreatic ductal adenocarcinoma (PDAC) cells and caused cell cycle arrest in G2. These results were confirmed in vivo as 6 exhibited anti-tumor activity in a human pancreatic tumor xenograft mouse model associated with decrease of H3K9 acetylation levels. In addition, a preliminary study in male Sprague-Dawley rats indicated a promising pharmacokinetic profile, although the bioavailability was only $4 \%$. Notwithstanding the low bioavailability, 6 has a good pharmacokinetic profile and is the most potent SIRT6 activator described so far. With its low micromolar $\mathrm{EC}_{50}$ and in vivo efficacy, it is an ideal lead compound for further development of potent and selective activators of SIRT6 with improved bioavailability that might be promoted to the clinical phase.

\subsection{SIRT6 Inhibitors}

Given the double-faced involvement of SIRT6 in cancer and inflammation, the inhibition of SIRT6 in specific contexts may also represent a successful strategy for cancer treatment. Indeed, inhibitors may target different SIRT6-mediated pathways contributing to cancer progression such as DNA repair mechanisms, cell differentiation and inflammatory response (Table 4). 
Table 4. Most relevant SIRT6 inhibitors.

\begin{tabular}{|c|c|c|c|c|}
\hline Compound & Structure & $\begin{array}{c}\text { Effect on SIRT6 } \\
\text { Activity }\end{array}$ & Cellular and In Vivo Effects & Reference(s) \\
\hline $\begin{array}{c}\mathbf{9 b} \\
\text { BHJH-TM3 }\end{array}$ & & $\begin{array}{c}\mathrm{IC}_{50}=8.1 \mu \mathrm{M} \\
\text { (demyristoylation) }\end{array}$ & $\begin{array}{l}\text { - } \quad \text { SIRT6 inhibition and decreased } \\
\text { TNF- } \alpha \text { fatty acylation in } \\
\text { HEK293T cells. }\end{array}$ & {$[114]$} \\
\hline 11b OSS_128167 & & $\begin{array}{c}\mathrm{IC}_{50}=89 \mu \mathrm{M} \\
\text { (deacetylation) }\end{array}$ & $\begin{array}{l}\text { Augmented H3K9 acetylation and } \\
\text { TNF- } \alpha \text { secretion in BxPC3 cells. } \\
\text { GLUT1 upregulation and } \\
\text { consequent increased glucose } \\
\text { uptake in L6 rat myoblasts and } \\
\text { BxPC3 cells. } \\
\text { - Sensitization of MM cell lines to } \\
\text { DNA-damaging agents. } \\
\text { Suppression of DLBCL cell } \\
\text { proliferation; induction of } \\
\text { apoptosis and cell cycle arrest. } \\
\text { Tumor growth reduction in DLBCL } \\
\text { mouse xenograft. }\end{array}$ & $\begin{array}{l}\text { [115] } \\
\text { [96] } \\
\text { [91] }\end{array}$ \\
\hline $12 b$ & & $\begin{array}{c}\mathrm{IC}_{50}=37 \mu \mathrm{M} \\
\text { (deacetylation) }\end{array}$ & $\begin{array}{l}\text { Increased H3K9 acetylation in } \\
\text { BxPC3. Augmented glucose uptake } \\
\text { in L6 rat myoblasts and BxPC3 } \\
\text { cells. Sensitization of BxPC3 cells to } \\
\text { gemcitabine. } \\
\text { Enhancement of olaparib } \\
\text { anticancer activity in Capan-1 cells. }\end{array}$ & [116] \\
\hline $13 b$ & & $\begin{array}{c}\mathrm{IC}_{50}=22 \mu \mathrm{M} \\
\text { (deacetylation) }\end{array}$ & $\begin{array}{l}\text { - Increased H3K9 acetylation and } \\
\text { glucose uptake in PBMCs. } \\
\text { Impaired TNF- } \alpha \text { secretion and T } \\
\text { lymphocyte proliferation. } \\
\text { Sensitization of pancreatic cancer } \\
\text { cells to gemcitabine. }\end{array}$ & [117] \\
\hline $\begin{array}{l}\text { 14a } \\
\text { A127-(CONHPr)- } \\
\text { B178 }\end{array}$ & & $\begin{array}{c}\mathrm{IC}_{50}=6.7 \mu \mathrm{M} \\
\text { (demyristoylation) }\end{array}$ & $\begin{array}{l}\text { Increase of DNA-damage markers } \\
\text { and telomere-dysfunction induced } \\
\text { foci in HUVECs. Reduction in } \\
\text { TNF- } \alpha \text { levels. }\end{array}$ & [118] \\
\hline 15 & & $\begin{array}{l}\mathrm{IC}_{50}=4.93 \mu \mathrm{M} \\
\text { (deacetylation) }\end{array}$ & $\begin{array}{l}\text { Dose-dependent increase of H3K9 } \\
\text { and H3K18 acetylation levels in } \\
\text { BxPC-3 cells. Increased GLUT-1 } \\
\text { expression levels. Reduction of } \\
\text { blood glucose content in a mouse } \\
\text { model of type } 2 \text { diabetes. }\end{array}$ & [119] \\
\hline
\end{tabular}

Product-based inhibitors such as nicotinamide (7a) and its derivatives, as well as ADP-ribose (8) (Figure 5) presented $\mathrm{IC}_{50}$ values in the mid-micromolar range, although the selectivity was absent or not tested. Nicotinamide showed $\mathrm{IC}_{50}$ values for the demyristoylation activity between $73 \mu \mathrm{M}$ and $184 \mu \mathrm{M}$ depending on the assay conditions [120,121]. Nicotinamide derivatives based on pyrazinamide showed improved SIRT6 inhibitory activity: 5-MeO-PZA (7b) and 5-Cl-PZA (7c) had $\mathrm{IC}_{50}$ values of $40.4 \mu \mathrm{M}$ and $33.2 \mu \mathrm{M}$, respectively [122]. ADP-ribose (8) also inhibits SIRT6 activity and shows higher potency than nicotinamide with $\mathrm{IC}_{50}$ values of $74 \mu \mathrm{M}$ (deoctanoylation) and $89 \mu \mathrm{M}$ (demyristoylation), compared to values of $150 \mu \mathrm{M}$ and $120 \mu \mathrm{M}$, respectively, for nicotinamide [123]. 


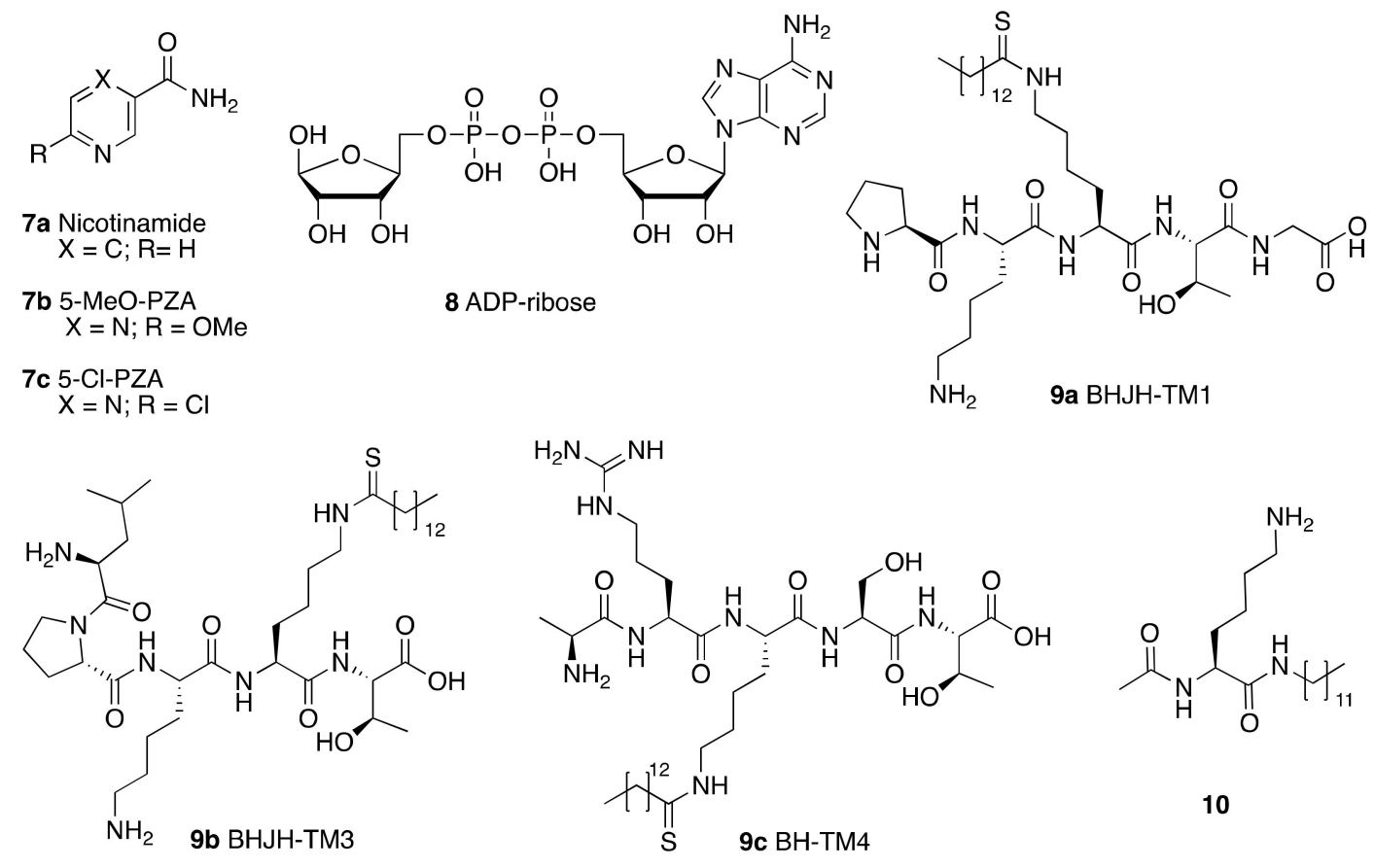

Figure 5. Product- (7-8) and substrate-based (9-10) SIRT6 inhibitors.

Another class of inhibitors directly related to the SIRT6 enzymatic mechanism of action are $\mathrm{N}^{\varepsilon}$-thioacyl-lysine-containing peptides, which lock the catalytic cycle at the first step, i.e., the nucleophilic attack to the (thio)carbonyl of the acyl group [124]. Thiomyristoyl peptides BHJH-TM1 (9a), BHJH-TM3 (9b), and BH-TM4 (9c) (Figure 5) are based on known SIRT6 substrates (i.e., TNF- $\alpha-K 20$, TNF- $\alpha-K 19$ and H3K9 peptides) [114]. Their IC $_{50}$ values for demyristoylation were $2.8 \mu \mathrm{M}, 8.1 \mu \mathrm{M}$ and $1.7 \mu \mathrm{M}$, respectively, though they lacked selectivity due to the concomitant inhibition of SIRT1-3. 9c was also tested in a deacetylation activity assay, showing an $\mathrm{IC}_{50}$ of $8.2 \mu \mathrm{M}$. Notwithstanding their peptide nature, these compounds were also active in HEK293T cells, displaying SIRT6 inhibition and increased TNF- $\alpha$ fatty acylation, with $\mathbf{9 b}$ being the most potent. This result may be explained by the presence of a hydrophobic myristoyl group which can increase their cell permeability.

Another substrate-based compound targeting SIRT6 deacylase activities has been developed using a lysine residue as starting scaffold (10) (Figure 5) [125]. This molecule consists of a lysine where the amidic nitrogen is bound to a 12-carbon alkyl chain and the $\mathrm{C} \alpha$ amine is acetylated. Compound 10 inhibited SIRT6 deacetylation $\left(\mathrm{IC}_{50}=95 \mu \mathrm{M}\right)$ without isoform specificity as it also decreased SIRT1,2 activities with comparable potency. Interestingly, it enhanced demyristoylation $\left(\mathrm{EC}_{50}=70 \mu \mathrm{M}\right)$ and depalmitoylation $(80 \%$ activation of at $100 \mu \mathrm{M}$ ), while still acting as an inhibitor for SIRT1 and SIRT2 deacylation. Nonetheless, MCF-7 breast cancer cell lines treatment with 10 resulted in increased H3K9Ac levels, intensification of the activities of glycolysis enzymes and decreased TNF- $\alpha$ secretion. This phenotype is in line with SIRT6 involvement in downregulation of glycolytic enzymes and its ability in triggering TNF- $\alpha$ secretion $[12,126]$. The results of this study are rather surprising in light of the previously cited evidence that FFA increase the deacetylation activity SIRT6 and inhibit deacylation [11]. Based on in silico data, the authors speculate that the acetyl moiety bound to the $\mathrm{C} \alpha$ amine group may mimic the acetylated substrate, being close to $\mathrm{NAD}^{+}$, in accordance with the experimental evidence suggesting competition of 10 with the acetylated substrate, rather than with $\mathrm{NAD}^{+}$. Nevertheless, further experimental evidence is required to clarify the binding mode and to account for the differential SIRT6 modulation profile.

An in silico screening led to the identification of compounds $11 a-c\left(\mathrm{IC}_{50} \mathrm{~s}=106 \mu \mathrm{M}\right.$, $89 \mu \mathrm{M}$, and $181 \mu \mathrm{M}$, respectively) as the first SIRT6-inhibiting small molecules (Figure 6) [115]. 
Whilst 11a showed mild selectivity over SIRT1, but not SIRT2, 11b (later named OSS_128167) and 11c were selective over both isoforms. The three compounds increased H3K9 acetylation in BxPC3 cells and induced GLUT1 upregulation and consequent increase of glucose uptake in L6 rat myoblasts and BxPC3 cells [66]. In addition, all compounds decreased TNF- $\alpha$ release. The effects of compounds 11a-c are in line with the reported SIRT6 physiological roles and mimic the phenotypes observed following SIRT6 knockdown. Recently, 11a showed improved glucose tolerance in a mouse model of type 2 diabetes mellitus, associated with reduced insulin, triglycerides, and cholesterol levels in plasma [127]. Compound 11b was able to sensitize primary MM cells, as well as melphalan- and doxorubicin-resistant MM cell lines, to chemotherapeutics inducing DNA-damage. Additionally, the authors of this study showed that $\mathbf{1 1 b}$ reduced recruitment of SIRT6 to DNA-damage sites [96]. When evaluated in DLBCL cells, that are characterized by overexpression of SIRT6, 11b decreased cell viability and suppressed proliferation in a time- and dose-dependent manner. In line with this, induction of apoptosis along with cell cycle arrest at G2/M were observed. This compound showed also in vivo efficacy in a mouse xenograft model, where it decreased tumor growth and lowered the levels of the proliferative marker Ki-67 [91].

Compound 11a was the lead molecule for the development of the series of quinazolinedione derivatives 12a-c (Figure 6) [116], that are characterized by different substituents on the sulfonamide residue. These molecules showed improved SIRT6 inhibition $\left(\mathrm{IC}_{50}(\mathbf{1 2 a})=60 \mu \mathrm{M} ; \mathrm{IC}_{50}(\mathbf{1 2 b})=37 \mu \mathrm{M} ; \mathrm{IC}_{50}(\mathbf{1 2} \mathbf{c})=49 \mu \mathrm{M}\right)$, as well as isoform selectivity over SIRT1,2. Whilst all derivatives augmented H3K9 acetylation in BxPC3 cells, only compounds 12b and 12c determined higher glucose uptake in BxPC3 cells, as well as L6 rat myoblasts. Remarkably, compounds 12a and 12b sensitized BxPC3 cells to the chemotherapeutic agent gemcitabine and intensified the DNA damage and cell death induced by the PARP inhibitor olaparib in Capan-1 cells (a BRCA2-deficient pancreatic cancer cell line). These observations are consistent with previous findings suggesting that SIRT6 knockdown can improve the efficacy of chemotherapeutics [84].

Compounds 13a-c (Figure 6) are the result of a ligand-based drug design approach that used $\mathbf{1 1 b}$ as starting scaffold. They possess $\mathrm{IC}_{50}$ values of $34 \mu \mathrm{M}, 22 \mu \mathrm{M}$, and $20 \mu \mathrm{M}$, respectively [117]. While $\mathbf{1 3}$ c was not cellularly active, $\mathbf{1 3 a}$ and $\mathbf{1 3 b}$ increased H3K9 acetylation and glucose uptake in human peripheral blood mononuclear cells (PBMCs). Compound $\mathbf{1 3 b}$ displayed anti-proliferative effects in the same cell line. In addition, both 13a and 13b diminished TNF- $\alpha$ secretion and sensitized pancreatic cancer cells to gemcitabine [117].

A drug screening using DNA-encoded libraries designed for NAD ${ }^{+}$-binding pockets led to the identification of the SIRT6 inhibitors A127-(CONHPr)-B178 (14a) and A127(CONHMe)-B178 (14b) (Figure 6), possessing $\mathrm{IC}_{50}$ values for demyristoylation in the low micromolar range $(6.7 \mu \mathrm{M}$ and $9.2 \mu \mathrm{M}$, respectively) [128]. Compound 14a was selective over other sirtuins and was stable in serum after $72 \mathrm{~h}$ incubation. Like other inhibitors, 14a caused dose-dependent decrease in the TNF- $\alpha$ levels. Moreover, treatment of primary human umbilical venous endothelial cells (HUVECs) with 14a caused an increase of DNAdamage markers and telomere-dysfunction induced foci, similarly to what observed with SIRT6 knockdown [118].

Finally, the 1-phenylpiperazine derivative (15) (Figure 6) displayed selective and potent inhibition of SIRT6, with an $\mathrm{IC}_{50}$ of $4.93 \mu \mathrm{M}$ in a peptide deacetylation assay [119]. When tested in BxPC-3 cells 15 augmented H3K9Ac and H3K18Ac levels, and enhanced GLUT-1 expression. Even more importantly, it had in vivo effects since it reduced the blood glucose content in a mouse model of type 2 diabetes, demonstrating promising drug-like properties. 
<smiles>[R20]NS(=O)(=O)c1ccc2c(c1)c(=O)n([R16])c(=O)n2[R16]</smiles><smiles>[R16]C=[18O]</smiles><smiles>[R6]C=[Pb]</smiles>

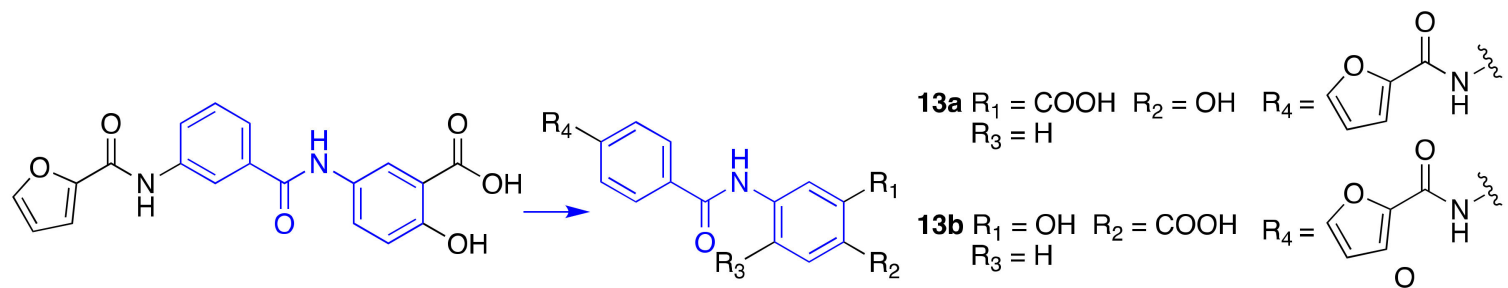<smiles>N=C(Nc1ccccc1)SC1CC(=O)N(c2ccc(C(=O)O)cc2)C1=O</smiles>

11c<smiles>[R]NC(=O)[C@H](CNC(=O)Cn1cc(C(N)=O)c(=O)[nH]c1=O)NC(=O)CCc1nc(-c2cccnc2)no1</smiles>

14a $\mathrm{A} 127-(\mathrm{CONHPr})-\mathrm{B} 178 \mathrm{R}=\mathrm{CH}_{2} \mathrm{CH}_{2} \mathrm{CH}_{3}$

14b A127-(CONHMe)-B178 $\mathrm{R}=\mathrm{CH}_{3}$

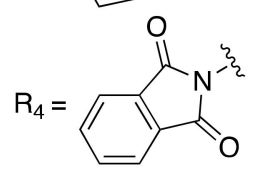

Figure 6. Synthetic SIRT6 inhibitors.

\section{Conclusions and Perspectives}

Over the past decade, the elucidation of SIRT6 manifold functions has stimulated several studies on the connection between SIRT6 activity and both physiological and pathological conditions. Given the key role that SIRT6 plays in homeostasis regulation, it is not surprising that its function regulates cancer onset and progression. Its dual role in cancer is yet to be fully understood, however different reports point towards a context- and tissue-dependence. SIRT6-mediated DNA repair initially protects from tumor transformation, while promotes cancer cell survival at later stages. Importantly, the increase of SIRT6 levels in certain types of cancer may also represent an adaptation mechanism against genomic instability [96].

Several efforts have been dedicated to the improvement of anticancer therapies due to the emergence of resistance to chemotherapy, the low efficacy of different drugs and the high recurrence rate after surgery. Understanding the outcomes of different cellular pathways, such as the activation of programmed cell death and their involvement in tumorigenesis, will increase the efficacy of therapeutic strategies, strengthening the already well-known concept of personalized therapy. In the case of SIRT6, given its multifaceted role in cancer, the concept of personalized medicine becomes central: there is need for both activators and inhibitors, depending not only on the cancer type, but also likely on the stage of the disease. The modulation of cell proliferation and death, as well as the regulation of several factors linked to the tumor initiation, progression and metastatization, makes it a potential target for future personalized therapies. 
The road to the discovery of potent and selective SIRT6 modulators is still at its infancy. Nonetheless, activators endowed with cellular activity such as UBCS039 (4), MDL-800 (5a), and MDL-811 (5c) have been described, with the two MDL compounds also showing in vivo efficacy. Notably, the UBCS039-SIRT6 co-crystal paved the way for structure-based discovery of compound 6, possessing anti-tumor activity both in vitro and in vivo. Amongst these activators, $5 c$ and 6 represent the best lead compounds for the further optimization toward clinical candidates, most likely in the context of anti-cancer combination therapy.

As for the inhibitors, only one compound (11b) displayed anti-tumor activity in vivo. The structural optimization of $11 \mathrm{~b}$ to increase its potency and PK properties represents a necessary step for the development of SIRT6 inhibitors with a solid therapeutic potential in cancer. Compound 15 had in vivo efficacy, although it was not tested in cancer models. Notably, this molecule is relatively simple and may act as lead compound for further optimization studies.

The elucidation of SIRT6-drug interactions at structural level will be crucial in the next future for the design of potent modulators. Novel molecules will help to dissect the details underpinning SIRT6 involvement in cancer but may also be proposed soon as drugs to be used in monotherapy or combined therapy to tackle different types of tumors.

Author Contributions: D.R., A.M. and L.A. conceptualized and designed the review; F.F., V.C. and G.F. performed the literature search and wrote the paper; F.F. and G.F. created the tables and figures. All authors have read and agreed to the published version of the manuscript.

Funding: This work was supported by PRIN 2016 (prot. 20152TE5PK) (L.A, A.M.), AIRC 2016 (n. 19162) (A.M.), Progetto di Ateneo “Sapienza" 2017 n. RM11715C7CA6CE53 (D.R.), VALERE Vanvitelli per la Ricerca Program 2020 ("MAGICA") (V.C.), Ministero della Salute (RF-2018-12366268) (V.C.), iCURE (CUP B21c17000030007) (L.A.), MIUR Proof of Concept (POC01_00043) (L.A.).

Conflicts of Interest: The authors declare no conflict of interest.

\author{
Abbreviations \\ ADP Adenosine diphosphate \\ AML Acute myeloid leukemia; \\ AMP Adenosine monophosphate \\ AP-1 Activator protein 1 \\ ATP Adenosine triphosphate \\ AMPK AMP-activated protein kinase \\ Bax Bcl-2 associated $X$ protein \\ BER Base excision repair \\ cAMP Cyclic adenosine monophosphate \\ CHIP Carboxyl terminus of Hsp70-Interacting protein \\ CREB cAMP response element-binding protein \\ DSB Double strand break \\ DLBCL Diffuse large B-cell lymphoma \\ $\mathrm{EC}_{50} \quad$ Half maximal effective concentration \\ EMT Epithelial-mesenchymal transition \\ FFA Free fatty acid \\ HCC Hepatocellular carcinoma \\ HDAC Histone deacetylase \\ HIF- $\alpha \quad$ Hypoxia-inducible factor $1 \alpha$ \\ HP1 $\alpha \quad$ Heterochromatin protein $1 \alpha$; \\ HR Homologous recombination \\ $\mathrm{IC}_{50} \quad$ Half maximal inhibitory concentration \\ IGF Insulin-like growth factor \\ IGFBP2 Insulin-like growth factor-binding protein 2
}




$\begin{array}{ll}\text { IL-6 } & \text { Interleukin-6 } \\ \text { IL-8 } & \text { Interleukin-8 } \\ \text { IPSCs } & \text { Induced pluripotent stem cells } \\ \text { L1 } & \text { Long interspersed element 1 } \\ \text { MAPK } & \text { Mitogen-activated protein kinase } \\ \text { MDM2 } & \text { Mouse double minute } 2 \text { homolog } \\ \text { miRNA } & \text { micro-RNA } \\ \text { MM } & \text { Multiple myeloma } \\ \text { NAD } & \text { Nicotinamide adenine dinucleotide } \\ \text { NHEJ } & \text { Non-homologous end-joining } \\ \text { NPC } & \text { Nasopharyngeal carcinoma } \\ \text { NSCLC } & \text { Non-small cell lung cancer } \\ \text { PARP1 } & \text { Poly [ADP-ribose] polymerase 1 } \\ \text { PCPB2 } & \text { Poly(C)-binding protein 2 } \\ \text { PCD } & \text { Programmed cell death } \\ \text { PDAC } & \text { Pancreatic ductal adenocarcinoma } \\ \text { PKA } & \text { Protein kinase A } \\ \text { PKM2 } & \text { Pyruvate kinase M2 } \\ \text { ROS } & \text { Reactive oxygen species } \\ \text { SIRT } & \text { Sirtuin } \\ \text { SCC } & \text { Skin squamous cell carcinoma } \\ \text { SUMO } & \text { Small ubiquitin-related modifier } \\ \text { TNF- } \alpha & \text { Tumor necrosis factor } \alpha \\ \text { TRF2 } & \text { Telomere repeat binding factor 2 } \\ \text { UTR } & \text { Untranslated region } \\ \text { XIAP } & \text { X-linked inhibitor of apoptosis protein } \\ & \end{array}$

\section{References}

1. Finkel, T.; Deng, C.X.; Mostoslavsky, R. Recent progress in the biology and physiology of sirtuins. Nature 2009, 460, 587-591. [CrossRef]

2. Michishita, E.; McCord, R.A.; Berber, E.; Kioi, M.; Padilla-Nash, H.; Damian, M.; Cheung, P.; Kusumoto, R.; Kawahara, T.L.A.; Barrett, J.C.; et al. SIRT6 is a histone H3 lysine 9 deacetylase that modulates telomeric chromatin. Nature 2008, 452, $492-496$. [CrossRef]

3. Michishita, E.; McCord, R.A.; Boxer, L.D.; Barber, M.F.; Hong, T.; Gozani, O.; Chua, K.F. Cell cycle-dependent deacetylation of telomeric histone H3 lysine K56 by human SIRT6. Cell Cycle 2009, 8, 2664-2666. [CrossRef] [PubMed]

4. Yang, B.; Zwaans, B.M.M.; Eckersdorff, M.; Lombard, D.B. The sirtuin SIRT6 deacetylates H3 K56Ac in vivo to promote genomic stability. Cell Cycle 2009, 8, 2662-2663. [CrossRef]

5. Tasselli, L.; Xi, Y.; Zheng, W.; Tennen, R.I.; Odrowaz, Z.; Simeoni, F.; Li, W.; Chua, K.F. SIRT6 deacetylates H3K18ac at pericentric chromatin to prevent mitotic errors and cellular senescence. Nat. Struct. Mol. Biol. 2016, 23, 434-440. [CrossRef]

6. Chang, A.R.; Ferrer, C.M.; Mostoslavsky, R. SIRT6, a mammalian deacylase with multitasking abilities. Physiol. Rev. 2020, 100, 145-169. [CrossRef] [PubMed]

7. Klein, M.A.; Denu, J.M. Biological and catalytic functions of sirtuin 6 as targets for small-molecule modulators. J. Biol. Chem. 2020, 295, 11021-11041. [CrossRef]

8. Michishita, E.; Park, J.Y.; Burneskis, J.M.; Barrett, J.C.; Horikawa, I. Evolutionarily Conserved and Nonconserved Cellular Localizations and Functions of Human SIRT Proteins. Mol. Biol. Cell 2005, 16, 4623-4635. [CrossRef]

9. Beauharnois, J.M.; Bolivar, B.E.; Welch, J.T. Sirtuin 6: A review of biological effects and potential therapeutic properties. Mol. Biosyst. 2013, 9, 1789-1806. [CrossRef]

10. Pan, P.W.; Feldman, J.L.; Devries, M.K.; Dong, A.; Edwards, A.M.; Denu, J.M. Structure and biochemical functions of SIRT6. J. Biol. Chem. 2011, 286, 14575-14587. [CrossRef] [PubMed]

11. Feldman, J.L.; Baeza, J.; Denu, J.M. Activation of the protein deacetylase SIRT6 by long-chain fatty acids and widespread deacylation by Mammalian Sirtuins. J. Biol. Chem. 2013, 288, 31350-31356. [CrossRef] [PubMed]

12. Jiang, H.; Khan, S.; Wang, Y.; Charron, G.; He, B.; Sebastian, C.; Du, J.; Kim, R.; Ge, E.; Mostoslavsky, R.; et al. SIRT6 regulates TNF- $\alpha$ secretion through hydrolysis of long-chain fatty acyl lysine. Nature 2013, 496, 110-113. [CrossRef]

13. Zhang, X.; Spiegelman, N.A.; Nelson, O.D.; Jing, H.; Lin, H. SIRT6 regulates Ras-related protein R-Ras2 by lysine defatty-acylation. eLife 2017, 6. [CrossRef]

14. Toiber, D.; Erdel, F.; Bouazoune, K.; Silberman, D.; Zhong, L.; Mulligan, P.; Sebastian, C.; Cosentino, C.; Martinez-Pastor, B.; Giacosa, S.; et al. SIRT6 recruits SNF2H to DNA break sites, preventing genomic instability through chromatin remodeling. Mol. Cell 2013, 51, 454-468. [CrossRef] 
15. Chen, W.; Liu, N.; Zhang, H.; Zhang, H.; Qiao, J.; Jia, W.; Zhu, S.; Mao, Z.; Kang, J. Sirt6 Promotes DNA End Joining in iPSCs Derived from Old Mice. Cell Rep. 2017, 18, 2880-2892. [CrossRef]

16. Mao, Z.; Hine, C.; Tian, X.; Van Meter, M.; Au, M.; Vaidya, A.; Seluanov, A.; Gorbunova, V. SIRT6 promotes DNA repair under stress by activating PARP1. Science 2011, 332, 1443-1446. [CrossRef]

17. Xu, Z.; Zhang, L.; Zhang, W.; Meng, D.; Zhang, H.; Jiang, Y.; Xu, X.; Van Meter, M.; Seluanov, A.; Gorbunova, V.; et al. SIRT6 rescues the age related decline in base excision repair in a PARP1-dependent manner. Cell Cycle 2015, 14, 269-276. [CrossRef] [PubMed]

18. Hwang, B.J.; Jin, J.; Gao, Y.; Shi, G.; Madabushi, A.; Yan, A.; Guan, X.; Zalzman, M.; Nakajima, S.; Lan, L.; et al. SIRT6 protein deacetylase interacts with MYH DNA glycosylase, APE1 endonuclease, and Rad9-Rad1-Hus1 checkpoint clamp. BMC Mol. Biol. 2015, 16. [CrossRef]

19. Tennen, R.I.; Bua, D.J.; Wright, W.E.; Chua, K.F. SIRT6 is required for maintenance of telomere position effect in human cells. Nat. Commun. 2011, 2. [CrossRef]

20. Multani, A.S.; Chang, S. WRN at telomeres: Implications for aging and cancer. J. Cell Sci. 2007, 120, 713-721. [CrossRef] [PubMed]

21. Rizzo, A.; Iachettini, S.; Salvati, E.; Zizza, P.; Maresca, C.; D’Angelo, C.; Benarroch-Popivker, D.; Capolupo, A.; Del Gaudio, F.; Cosconati, S.; et al. SIRT6 interacts with TRF2 and promotes its degradation in response to DNA damage. Nucleic Acids Res. 2017, 45, 1820-1834. [CrossRef]

22. Van Meter, M.; Kashyap, M.; Rezazadeh, S.; Geneva, A.J.; Morello, T.D.; Seluanov, A.; Gorbunova, V. SIRT6 represses LINE1 retrotransposons by ribosylating KAP1 but this repression fails with stress and age. Nat. Commun. 2014, 5. [CrossRef]

23. Imai, S.-I.; Guarente, L. It takes two to tango: $\mathrm{NAD}(+)$ and sirtuins in aging/longevity control. Npj Aging Mech. Dis. 2016, 2. [CrossRef] [PubMed]

24. Mostoslavsky, R.; Chua, K.F.; Lombard, D.B.; Pang, W.W.; Fischer, M.R.; Gellon, L.; Liu, P.; Mostoslavsky, G.; Franco, S.; Murphy, M.M.; et al. Genomic instability and aging-like phenotype in the absence of mammalian SIRT6. Cell 2006, 124, 315-329. [CrossRef]

25. Kanfi, Y.; Naiman, S.; Amir, G.; Peshti, V.; Zinman, G.; Nahum, L.; Bar-Joseph, Z.; Cohen, H.Y. The sirtuin SIRT6 regulates lifespan in male mice. Nature 2012, 483, 218-221. [CrossRef]

26. Sebastián, C.; Zwaans, B.M.M.; Silberman, D.M.; Gymrek, M.; Goren, A.; Zhong, L.; Ram, O.; Truelove, J.; Guimaraes, A.R.; Toiber, D.; et al. The histone deacetylase SIRT6 Is a tumor suppressor that controls cancer metabolism. Cell 2012, 151, 1185-1199. [CrossRef] [PubMed]

27. Bauer, I.; Grozio, A.; Lasiglie, D.; Basile, G.; Sturla, L.; Magnone, M.; Sociali, G.; Soncini, D.; Caffa, I.; Poggi, A.; et al. The NAD+dependent histone deacetylase SIRT6 promotes cytokine production and migration in pancreatic cancer cells by regulating Ca $2+$ responses. J. Biol. Chem. 2012, 287, 40924-40937. [CrossRef]

28. Kawahara, T.L.A.; Michishita, E.; Adler, A.S.; Damian, M.; Berber, E.; Lin, M.; McCord, R.A.; Ongaigui, K.C.L.; Boxer, L.D.; Chang, H.Y.; et al. SIRT6 Links Histone H3 Lysine 9 Deacetylation to NF-kB-Dependent Gene Expression and Organismal Life Span. Cell 2009, 136, 62-74. [CrossRef]

29. Zhang, N.; Li, Z.; Mu, W.; Li, L.; Liang, Y.; Lu, M.; Wang, Z.; Qiu, Y.; Wang, Z. Calorie restriction-induced SIRT6 activation delays aging by suppressing NF-kB signaling. Cell Cycle 2016, 15, 1009-1018. [CrossRef]

30. Lee, Y.; Ka, S.O.; Cha, H.N.; Chae, Y.N.; Kim, M.K.; Park, S.Y.; Bae, E.J.; Park, B.H. Myeloid sirtuin 6 deficiency causes insulin resistance in high-fat diet-fed mice by eliciting macrophage polarization toward an M1 phenotype. Diabetes 2017, 66, 2659-2668. [CrossRef] [PubMed]

31. Ouyang, L.; Shi, Z.; Zhao, S.; Wang, F.T.; Zhou, T.T.; Liu, B.; Bao, J.K. Programmed cell death pathways in cancer: A review of apoptosis, autophagy and programmed necrosis. Cell Prolif. 2012, 45, 487-498. [CrossRef]

32. Van Meter, M.; Mao, Z.; Gorbunova, V.; Seluanov, A. SIRT6 overexpression induces massive apoptosis in cancer cells but not in normal cells. Cell Cycle 2011, 10, 3153-3158. [CrossRef]

33. Kugel, S.; Feldman, J.L.; Klein, M.A.; Silberman, D.M.; Sebastián, C.; Mermel, C.; Dobersch, S.; Clark, A.R.; Getz, G.; Denu, J.M.; et al. Identification of and Molecular Basis for SIRT6 Loss-of-Function Point Mutations in Cancer. Cell Rep. 2015, 13, 479-488. [CrossRef] [PubMed]

34. Qu, N.; Hu, J.Q.; Liu, L.; Zhang, T.T.; Sun, G.H.; Shi, R.L.; Ji, Q.H. SIRT6 is upregulated and associated with cancer aggressiveness in papillary thyroid cancer via BRAF/ERK/Mcl1 pathway. Int. J. Oncol. 2017, 50, 1683-1692. [CrossRef] [PubMed]

35. De Ceu Teixeira, M.; Sanchez-Lopez, E.; Espina, M.; Garcia, M.L.; Durazzo, A.; Lucarini, M.; Novellino, E.; Souto, S.B.; Santini, A.; Souto, E.B. Sirtuins and SIRT6 in Carcinogenesis and in Diet. Int. J. Mol. Sci. 2019, 20. [CrossRef]

36. McGlynn, L.M.; Zino, S.; MacDonald, A.I.; Curle, J.; Reilly, J.E.; Mohammed, Z.M.; McMillan, D.C.; Mallon, E.; Payne, A.P.; Edwards, J.; et al. SIRT2: Tumour suppressor or tumour promoter in operable breast cancer? Eur. J. Cancer 2014, 50, $290-301$. [CrossRef]

37. Li, Z.; Xie, Q.R.; Chen, Z.; Lu, S.; Xia, W. Regulation of SIRT2 levels for human non-small cell lung cancer therapy. Lung Cancer 2013, 82, 9-15. [CrossRef] [PubMed]

38. Karwaciak, I.; Salkowska, A.; Karas, K.; Sobalska-Kwapis, M.; Walczak-Drzewiecka, A.; Pulaski, L.; Strapagiel, D.; Dastych, J.; Ratajewski, M. SIRT2 Contributes to the Resistance of Melanoma Cells to the Multikinase Inhibitor Dasatinib. Cancers 2019, 11. [CrossRef] 
39. Min, L.; Ji, Y.; Bakiri, L.; Qiu, Z.; Cen, J.; Chen, X.; Chen, L.; Scheuch, H.; Zheng, H.; Qin, L.; et al. Liver cancer initiation is controlled by AP-1 through SIRT6-dependent inhibition of survivin. Nat. Cell Biol. 2012, 14, 1203-1211. [CrossRef] [PubMed]

40. Wu, M.; Seto, E.; Zhang, J. E2F1 enhances glycolysis through suppressing Sirt6 transcription in cancer cells. Oncotarget 2015, 6, 11252-11263. [CrossRef]

41. Wencel, P.L.; Lukiw, W.J.; Strosznajder, J.B.; Strosznajder, R.P. Inhibition of Poly(ADP-ribose) Polymerase-1 Enhances Gene Expression of Selected Sirtuins and APP Cleaving Enzymes in Amyloid Beta Cytotoxicity. Mol. Neurobiol. 2018, 55, 4612-4623. [CrossRef]

42. Dávalos, A.; Goedeke, L.; Smibert, P.; Ramirez, C.M.; Warrier, N.P.; Andreo, U.; Cirera-Salinas, D.; Rayner, K.; Suresh, U.; Pastor-Pareja, J.C.; et al. miR-33a/b contribute to the regulation of fatty acid metabolism and insulin signaling. Proc. Natl. Acad. Sci. USA 2011, 108, 9232-9237. [CrossRef]

43. Elhanati, S.; Kanfi, Y.; Varvak, A.; Roichman, A.; Carmel-Gross, I.; Barth, S.; Gibor, G.; Cohen, H. Multiple regulatory layers of SREBP1/2 by SIRT6. Cell Rep. 2013, 4, 905-912. [CrossRef] [PubMed]

44. Chang, M.; Qiao, L.; Li, B.; Wang, J.; Zhang, G.; Shi, W.; Liu, Z.; Gu, N.; Di, Z.; Wang, X.; et al. Suppression of SIRT6 by miR-33a facilitates tumor growth of glioma through apoptosis and oxidative stress resistance. Oncol. Rep. 2017, 38, 1251-1258. [CrossRef]

45. Lefort, K.; Brooks, Y.; Ostano, P.; Cario-André, M.; Calpini, V.; Guinea-Viniegra, J.; Albinger-Hegyi, A.; Hoetzenecker, W.; Kolfschoten, I.; Wagner, E.F.; et al. A miR-34a-SIRT6 axis in the squamous cell differentiation network. EMBO J. 2013, 32, 2248-2263. [CrossRef]

46. Baker, J.R.; Vuppusetty, C.; Colley, T.; Papaioannou, A.I.; Fenwick, P.; Donnelly, L.; Ito, K.; Barnes, P.J. Oxidative stress dependent microRNA-34a activation via PI3K $\alpha$ reduces the expression of sirtuin-1 and sirtuin-6 in epithelial cells. Sci. Rep. 2016, 6. [CrossRef]

47. Elhanati, S.; Ben-Hamo, R.; Kanfi, Y.; Varvak, A.; Glazz, R.; Lerrer, B.; Efroni, S.; Cohen, H.Y. Reciprocal Regulation between SIRT6 and miR-122 Controls Liver Metabolism and Predicts Hepatocarcinoma Prognosis. Cell Rep. 2016, 14, 234-242. [CrossRef] [PubMed]

48. Song, S.; Yang, Y.; Liu, M.; Liu, B.; Yang, X.; Yu, M.; Qi, H.; Ren, M.; Wang, Z.; Zou, J.; et al. MiR-125b attenuates human hepatocellular carcinoma malignancy through targeting SIRT6. Am. J. Cancer Res. 2018, 8, 993-1007. [PubMed]

49. Sharma, A.; Diecke, S.; Zhang, W.Y.; Lan, F.; He, C.; Mordwinkin, N.M.; Chua, K.F.; Wu, J.C. The role of SIRT6 protein in aging and reprogramming of human induced pluripotent stem cells. J. Biol. Chem. 2013, 288, 18439-18447. [CrossRef] [PubMed]

50. Thirumurthi, U.; Shen, J.; Xia, W.; LaBaff, A.M.; Wei, Y.; Li, C.W.; Chang, W.C.; Chen, C.H.; Lin, H.K.; Yu, D.; et al. MDM2mediated degradation of SIRT6 phosphorylated by AKT1 promotes tumorigenesis and trastuzumab resistance in breast cancer. Sci. Signal. 2014, 7. [CrossRef]

51. Kim, E.J.; Juhnn, Y.S. Cyclic AMP signaling reduces sirtuin 6 expression in non-small cell lung cancer cells by promoting ubiquitin-proteasomal degradation via inhibition of the Raf-MEK-ERK (raf/mitogen-activated extracellular signal-regulated kinase/ extracellular signal-regulated kinase) pathway. J. Biol. Chem. 2015, 290, 9604-9613. [CrossRef] [PubMed]

52. Ronnebaum, S.M.; Wu, Y.; McDonough, H.; Patterson, C. The ubiquitin ligase CHIP prevents sirT6 degradation through noncanonical ubiquitination. Mol. Cell. Biol. 2013, 33, 4461-4472. [CrossRef]

53. Lin, Z.; Yang, H.; Tan, C.; Li, J.; Liu, Z.; Quan, Q.; Kong, S.; Ye, J.; Gao, B.; Fang, D. USP10 Antagonizes c-Myc transcriptional activation through SIRT6 stabilization to suppress tumor formation. Cell Rep. 2013, 5, 1639-1649. [CrossRef] [PubMed]

54. Cai, J.; Zuo, Y.; Wang, T.; Cao, Y.; Cai, R.; Chen, F.L.; Cheng, J.; Mu, J. A crucial role of SUMOylation in modulating Sirt6 deacetylation of $\mathrm{H} 3$ at lysine 56 and its tumor suppressive activity. Oncogene 2016, 35, 4949-4956. [CrossRef] [PubMed]

55. Zhang, C.; Yu, Y.; Huang, Q.; Tang, K. SIRT6 regulates the proliferation and apoptosis of hepatocellular carcinoma via the ERK1/2 signaling pathway. Mol. Med. Rep. 2019, 20, 1575-1582. [CrossRef]

56. The Broad Institute of MIT \& Harvard. Cancer Cell Line Encyclopedia. Available online: https://portals.broadinstitute.org/ccle/ page?gene=SIRT6 (accessed on 6 March 2021).

57. Zhang, J.; Yin, X.J.; Xu, C.J.; Ning, Y.X.; Chen, M.; Zhang, H.; Chen, S.F.; Yao, L.Q. The histone deacetylase SIRT6 inhibits ovarian cancer cell proliferation via down-regulation of Notch 3 expression. Eur. Rev. Med. Pharmacol. Sci. 2015, 19, 818-824.

58. Jung, S.G.; Kwon, Y.D.; Song, J.A.; Back, M.J.; Lee, S.Y.; Lee, C.; Hwang, Y.Y.; An, H.J. Prognostic significance of Notch 3 gene expression in ovarian serous carcinoma. Cancer Sci. 2010, 101, 1977-1983. [CrossRef]

59. Chen, X.; Hao, B.; Liu, Y.; Dai, D.; Han, G.; Li, Y.; Wu, X.; Zhou, X.; Yue, Z.; Wang, L.; et al. The histone deacetylase SIRT6 suppresses the expression of the RNA-binding protein PCBP2 in glioma. Biochem. Biophys. Res. Commun. 2014, 446, 364-369. [CrossRef] [PubMed]

60. Makeyev, A.V.; Liebhaber, S.A. The poly(C)-binding proteins: A multiplicity of functions and a search for mechanisms. RNA 2002, 8. [CrossRef]

61. Zhang, Z.-G.; Qin, C.-Y. Sirt6 suppresses hepatocellular carcinoma cell growth via inhibiting the extracellular signal-regulated kinase signaling pathway. Mol. Med. Rep. 2014, 9, 882-888. [CrossRef]

62. Han, Z.; Liu, L.; Yaxin, L.; Shanqing, L. Sirtuin SIRT6 suppresses cell proliferation through inhibition of Twist1 expression in non-small cell lung cancer. Int. J. Clin. Exp. Pathol. 2014, 7, 4774-4781.

63. Ouyang, L.; Yi, L.; Li, J.; Yi, S.; Li, S.; Liu, P.; Yang, X. SIRT6 overexpression induces apoptosis of nasopharyngeal carcinoma by inhibiting NF-kappaB signaling. OncoTargets Ther. 2018, 11, 7613-7624. [CrossRef] 
64. Bhardwaj, A.; Das, S. SIRT6 deacetylates PKM2 to suppress its nuclear localization and oncogenic functions. Proc. Natl. Acad. Sci. USA 2016, 113, E538-E547. [CrossRef] [PubMed]

65. Kugel, S.; Sebastián, C.; Fitamant, J.; Ross, K.N.; Saha, S.K.; Jain, E.; Gladden, A.; Arora, K.S.; Kato, Y.; Rivera, M.N.; et al. SIRT6 suppresses pancreatic cancer through control of Lin28b. Cell 2016, 165, 1401-1415. [CrossRef]

66. Zhong, L.; D’Urso, A.; Toiber, D.; Sebastian, C.; Henry, R.E.; Vadysirisack, D.D.; Guimaraes, A.; Marinelli, B.; Wikstrom, J.D.; Nir, T.; et al. The Histone Deacetylase Sirt6 Regulates Glucose Homeostasis via Hif1 $\alpha$. Cell 2010, 140, 280-293. [CrossRef]

67. Warburg, O. On the origin of cancer cells. Science 1956, 123, 309-314. [CrossRef] [PubMed]

68. Li, N.; Mao, D.; Cao, Y.; Li, H.; Ren, F.; Li, K. Downregulation of SIRT6 by miR-34c-5p is associated with poor prognosis and promotes colon cancer proliferation through inhibiting apoptosis via the JAK2/STAT3 signaling pathway. Int. J. Oncol. 2018, 52, 1515-1527. [CrossRef] [PubMed]

69. Xia, Y.; Shen, S.; Verma, I.M. NF-kB, an active player in human cancers. Cancer Immunol. Res. 2014, 2, 823-830. [CrossRef]

70. Fukuda, T.; Wada-Hiraike, O.; Oda, K.; Tanikawa, M.; Makii, C.; Inaba, K.; Miyasaka, A.; Miyamoto, Y.; Yano, T.; Maeda, D.; et al. Putative tumor suppression function of SIRT6 in endometrial cancer. FEBS Lett. 2015, 589, 2274-2281. [CrossRef]

71. Dong, Z.; Yang, J.; Li, L.; Tan, L.; Shi, P.; Zhang, J.; Zhong, X.; Ge, L.; Wu, Z.; Cui, H. FOXO3aSIRT6 axis suppresses aerobic glycolysis in melanoma. Int. J. Oncol. 2020, 56, 728-742. [CrossRef] [PubMed]

72. Myatt, S.S.; Lam, E.W. The emerging roles of forkhead box (Fox) proteins in cancer. Nat. Rev. Cancer 2007, 7, 847-859. [CrossRef] [PubMed]

73. Skurk, C.; Maatz, H.; Kim, H.S.; Yang, J.; Abid, M.R.; Aird, W.C.; Walsh, K. The Akt-regulated forkhead transcription factor FOXO3a controls endothelial cell viability through modulation of the caspase-8 inhibitor FLIP. J. Biol. Chem. 2004, 279, 1513-1525. [CrossRef]

74. Ekoff, M.; Kaufmann, T.; Engstrom, M.; Motoyama, N.; Villunger, A.; Jonsson, J.I.; Strasser, A.; Nilsson, G. The BH3-only protein Puma plays an essential role in cytokine deprivation induced apoptosis of mast cells. Blood 2007, 110, 3209-3217. [CrossRef] [PubMed]

75. Yu, H.; Fellows, A.; Foote, K.; Yang, Z.; Figg, N.; Littlewood, T.; Bennett, M. FOXO3a (Forkhead Transcription Factor O Subfamily Member 3a) Links Vascular Smooth Muscle Cell Apoptosis, Matrix Breakdown, Atherosclerosis, and Vascular Remodeling Through a Novel Pathway Involving MMP13 (Matrix Metalloproteinase 13). Arter. Thromb. Vasc. Biol. 2018, 38, 555-565. [CrossRef]

76. Kops, G.J.P.L.; Dansen, T.B.; Polderman, P.E.; Saarloos, I.; Wirtz, K.W.A.; Coffer, P.J.; Huang, T.T.; Bos, J.L.; Medema, R.H.; Burgering, B.M.T. Forkhead transcription factor FOXO3a protects quiescent cells from oxidative stress. Nature 2002, 419, 316-321. [CrossRef]

77. Tao, R.; Xiong, X.; DePinho, R.A.; Deng, C.X.; Dong, X.C. Hepatic SREBP-2 and cholesterol biosynthesis are regulated by FoxO3 and Sirt6. J. Lipid Res. 2013, 54, 2745-2753. [CrossRef]

78. Tao, R.; Xiong, X.; DePinho, R.A.; Deng, C.X.; Dong, X.C. FoxO3 transcription factor and Sirt6 deacetylase regulate low density lipoprotein (LDL)-cholesterol homeostasis via control of the proprotein convertase subtilisin/kexin type 9 (Pcsk9) gene expression. J. Biol. Chem. 2013, 288, 29252-29259. [CrossRef] [PubMed]

79. Strub, T.; Ghiraldini, F.G.; Carcamo, S.; Li, M.; Wroblewska, A.; Singh, R.; Goldberg, M.S.; Hasson, D.; Wang, Z.; Gallagher, S.J.; et al. SIRT6 haploinsufficiency induces BRAFV600E melanoma cell resistance to MAPK inhibitors via IGF signalling. Nat. Commun. 2018, 9. [CrossRef]

80. Lu, C.T.; Hsu, C.M.; Lin, P.M.; Lai, C.C.; Lin, H.C.; Yang, C.H.; Hsiao, H.H.; Liu, Y.C.; Lin, H.Y.H.; Lin, S.F.; et al. The potential of SIRT6 and SIRT7 as circulating markers for head and neck squamous cell carcinoma. Anticancer Res. 2014, 34, 7137-7143.

81. Han, L.L.; Jia, L.; Wu, F.; Huang, C. Sirtuin6 (SIRT6) Promotes the EMT of Hepatocellular Carcinoma by Stimulating Autophagic Degradation of E-Cadherin. Mol. Cancer Res. 2019, 17, 2267-2280. [CrossRef]

82. Ran, L.K.; Chen, Y.; Zhang, Z.Z.; Tao, N.N.; Ren, J.H.; Zhou, L.; Tang, H.; Chen, X.; Chen, K.; Li, W.Y.; et al. SIRT6 overexpression potentiates apoptosis evasion in hepatocellular carcinoma via BCL2-associated X protein-dependent apoptotic pathway. Clin. Cancer Res. 2016, 22, 3372-3382. [CrossRef]

83. Zhou, H.Z.; Zeng, H.Q.; Yuan, D.; Ren, J.H.; Cheng, S.T.; Yu, H.B.; Ren, F.; Wang, Q.; Qin, Y.P.; Huang, A.L.; et al. NQO1 potentiates apoptosis evasion and upregulates XIAP via inhibiting proteasome-mediated degradation SIRT6 in hepatocellular carcinoma. Cell Commun. Signal 2019, 17, 168. [CrossRef]

84. Liu, Y.; Xie, Q.R.; Wang, B.; Shao, J.; Zhang, T.; Liu, T.; Huang, G.; Xia, W. Inhibition of SIRT6 in prostate cancer reduces cell viability and increases sensitivity to chemotherapeutics. Protein Cell 2013, 4, 702-710. [CrossRef]

85. Khongkow, M.; Olmos, Y.; Gong, C.; Gomesl, A.R.; Monteiro, L.J.; Yagüe, E.; Cavaco, T.B.; Khongkow, P.; Man, E.P.S.; Laohasinnarong, S.; et al. SIRT6 modulates paclitaxel and epirubicin resistance and survival in breast cancer. Carcinogenesis 2013, 34, 1476-1486. [CrossRef] [PubMed]

86. Ming, M.; Han, W.; Zhao, B.; Sundaresan, N.R.; Deng, C.X.; Gupta, M.P.; He, Y.Y. SIRT6 promotes COX-2 expression and acts as an oncogene in skin cancer. Cancer Res. 2014, 74, 5925-5933. [CrossRef]

87. Garcia-Peterson, L.M.; Ndiaye, M.A.; Singh, C.K.; Chhabra, G.; Huang, W.; Ahmad, N. SIRT6 histone deacetylase functions as a potential oncogene in human melanoma. Genes Cancer 2017, 8, 701-712. [CrossRef] 
88. Garcia-Peterson, L.M.; Ndiaye, M.A.; Chhabra, G.; Singh, C.K.; Guzman-Perez, G.; Iczkowski, K.A.; Ahmad, N. CRISPR/Cas9mediated Knockout of SIRT6 Imparts Remarkable Antiproliferative Response in Human Melanoma Cells in vitro and in vivo. Photochem. Photobiol. 2020, 96, 1314-1320. [CrossRef]

89. Wang, L.; Guo, W.; Ma, J.; Dai, W.; Liu, L.; Guo, S.; Chen, J.; Wang, H.; Yang, Y.; Yi, X.; et al. Aberrant SIRT6 expression contributes to melanoma growth: Role of the autophagy paradox and IGF-AKT signaling. Autophagy 2018, 14, 518-533. [CrossRef] [PubMed]

90. Garcia-Peterson, L.M.; Guzman-Perez, G.; Krier, C.R.; Ahmad, N. The sirtuin 6: An overture in skin cancer. Exp. Derm. 2020, 29, 124-135. [CrossRef] [PubMed]

91. Yang, J.; Li, Y.; Zhang, Y.; Fang, X.; Chen, N.; Zhou, X.; Wang, X. Sirt6 promotes tumorigenesis and drug resistance of diffuse large B-cell lymphoma by mediating PI3K/Akt signaling. J. Exp. Clin. Cancer Res. 2020, 39, 142. [CrossRef] [PubMed]

92. Cagnetta, A.; Soncini, D.; Orecchioni, S.; Talarico, G.; Minetto, P.; Guolo, F.; Retali, V.; Colombo, N.; Carminati, E.; Clavio, M.; et al. Depletion of SIRT6 enzymatic activity increases acute myeloid leukemia cells' vulnerability to DNA-damaging agents. Haematologica 2018, 103, 80-90. [CrossRef] [PubMed]

93. Speidel, D. Transcription-independent p53 apoptosis: An alternative route to death. Trends Cell Biol. 2010, 20, 14-24. [CrossRef]

94. Tao, N.N.; Ren, J.H.; Tang, H.; Ran, L.K.; Zhou, H.Z.; Liu, B.; Huang, A.L.; Chen, J. Deacetylation of Ku70 by SIRT6 attenuates Bax-mediated apoptosis in hepatocellular carcinoma. Biochem. Biophys. Res. Commun. 2017, 485, 713-719. [CrossRef] [PubMed]

95. Zhang, Z.; Ha, S.H.; Moon, Y.J.; Hussein, U.K.; Song, Y.; Kim, K.M.; Park, S.H.; Park, H.S.; Park, B.H.; Ahn, A.R.; et al. Inhibition of SIRT6 potentiates the anti-tumor effect of doxorubicin through suppression of the DNA damage repair pathway in osteosarcoma. J. Exp. Clin. Cancer Res. 2020, 39, 247. [CrossRef]

96. Cea, M.; Cagnetta, A.; Adamia, S.; Acharya, C.; Tai, Y.-T.; Fulciniti, M.; Ohguchi, H.; Munshi, A.; Acharya, P.; Bhasin, M.K.; et al. Evidence for a role of the histone deacetylase SIRT6 in DNA damage response of multiple myeloma cells. Blood 2016, 127, 1138-1150. [CrossRef]

97. Rahnasto-Rilla, M.; Kokkola, T.; Jarho, E.; Lahtela-Kakkonen, M.; Moaddel, R. N-Acylethanolamines Bind to SIRT6. ChemBioChem 2016, 17, 77-81. [CrossRef]

98. Rahnasto-Rilla, M.; Tyni, J.; Huovinen, M.; Jarho, E.; Kulikowicz, T.; Ravichandran, S.; Bohr, V.A.; Ferrucci, L.; Lahtela-Kakkonen, M.; Moaddel, R. Natural polyphenols as sirtuin 6 modulators. Sci. Rep. 2018, 8. [CrossRef]

99. You, W.; Rotili, D.; Li, T.M.; Kambach, C.; Meleshin, M.; Schutkowski, M.; Chua, K.F.; Mai, A.; Steegborn, C. Structural Basis of Sirtuin 6 Activation by Synthetic Small Molecules. Angew. Chem. Int. Ed. 2017, 56, 1007-1011. [CrossRef]

100. Iachettini, S.; Trisciuoglio, D.; Rotili, D.; Lucidi, A.; Salvati, E.; Zizza, P.; Di Leo, L.; Del Bufalo, D.; Ciriolo, M.R.; Leonetti, C.; et al. Pharmacological activation of SIRT6 triggers lethal autophagy in human cancer cells. Cell Death Dis. 2018, 9. [CrossRef]

101. Huang, Z.; Zhao, J.; Deng, W.; Chen, Y.; Shang, J.; Song, K.; Zhang, L.; Wang, C.; Lu, S.; Yang, X.; et al. Identification of a cellularly active SIRT6 allosteric activator. Nat. Chem. Biol. 2018, 14, 1118-1126. [CrossRef]

102. Shang, J.L.; Ning, S.B.; Chen, Y.Y.; Chen, T.X.; Zhang, J. MDL-800, an allosteric activator of SIRT6, suppresses proliferation and enhances EGFR-TKIs therapy in non-small cell lung cancer. Acta Pharmacologica Sinica 2020. [CrossRef]

103. Shang, J.; Zhu, Z.; Chen, Y.; Song, J.; Huang, Y.; Song, K.; Zhong, J.; Xu, X.; Wei, J.; Wang, C.; et al. Small-molecule activating SIRT6 elicits therapeutic effects and synergistically promotes anti-tumor activity of vitamin D3 in colorectal cancer. Theranostics 2020, 10, 5845-5864. [CrossRef]

104. Chen, X.; Sun, W.; Huang, S.; Zhang, H.; Lin, G.; Li, H.; Qiao, J.; Li, L.; Yang, S. Discovery of Potent Small-Molecule SIRT6 Activators: Structure-Activity Relationship and Anti-Pancreatic Ductal Adenocarcinoma Activity. J. Med. Chem. 2020, 63, 10474-10495. [CrossRef] [PubMed]

105. You, W.; Zheng, W.; Weiss, S.; Chua, K.F.; Steegborn, C. Structural basis for the activation and inhibition of Sirtuin 6 by quercetin and its derivatives. Sci. Rep. 2019, 9. [CrossRef] [PubMed]

106. Khan, D.; Sarikhani, M.; Dasgupta, S.; Maniyadath, B.; Pandit, A.S.; Mishra, S.; Ahamed, F.; Dubey, A.; Fathma, N.; Atreya, H.S.; et al. SIRT6 deacetylase transcriptionally regulates glucose metabolism in heart. J. Cell Physiol. 2018, 233, 5478-5489. [CrossRef] [PubMed]

107. Chen, Y.; Chen, J.; Sun, X.; Yu, J.; Qian, Z.; Wu, L.; Xu, X.; Wan, X.; Jiang, Y.; Zhang, J.; et al. The SIRT6 activator MDL-800 improves genomic stability and pluripotency of old murine-derived iPS cells. Aging Cell 2020, 19, e13185. [CrossRef] [PubMed]

108. Xu, P.; Wang, T.T.; Liu, X.Z.; Wang, N.Y.; Sun, L.H.; Zhang, Z.Q.; Chen, H.Z.; Lv, X.; Huang, Y.; Liu, D.P. Sirt6 regulates efficiency of mouse somatic reprogramming and maintenance of pluripotency. Stem Cell Res. 2019, 10, 9. [CrossRef]

109. Etchegaray, J.P.; Chavez, L.; Huang, Y.; Ross, K.N.; Choi, J.; Martinez-Pastor, B.; Walsh, R.M.; Sommer, C.A.; Lienhard, M.; Gladden, A.; et al. The histone deacetylase SIRT6 controls embryonic stem cell fate via TET-mediated production of 5-hydroxymethylcytosine. Nat. Cell Biol. 2015, 17, 545-557. [CrossRef]

110. Hobaus, J.; Hummel, D.M.; Thiem, U.; Fetahu, I.S.; Aggarwal, A.; Mullauer, L.; Heller, G.; Egger, G.; Mesteri, I.; BaumgartnerParzer, S.; et al. Increased copy-number and not DNA hypomethylation causes overexpression of the candidate proto-oncogene CYP24A1 in colorectal cancer. Int. J. Cancer 2013, 133, 1380-1388. [CrossRef]

111. Sun, H.; Wang, C.; Hao, M.; Sun, R.; Wang, Y.; Liu, T.; Cong, X.; Liu, Y. CYP24A1 is a potential biomarker for the progression and prognosis of human colorectal cancer. Hum. Pathol. 2016, 50, 101-108. [CrossRef]

112. Pereira, F.; Larriba, M.J.; Muñoz, A. Vitamin D and colon cancer. Endocr. Relat. Cancer 2012, 19, R51-R71. [CrossRef]

113. Ng, K.; Nimeiri, H.S.; McCleary, N.J.; Abrams, T.A.; Yurgelun, M.B.; Cleary, J.M.; Rubinson, D.A.; Schrag, D.; Miksad, R.; Bullock, A.J.; et al. Effect of High-Dose vs Standard-Dose Vitamin D3 Supplementation on Progression-Free Survival among Patients with Advanced or Metastatic Colorectal Cancer: The SUNSHINE Randomized Clinical Trial. JAMA 2019, 321, 1370-1379. [CrossRef] 
114. He, B.; Hu, J.; Zhang, X.; Lin, H. Thiomyristoyl peptides as cell-permeable Sirt6 inhibitors. Org. Biomol. Chem. 2014, 12, 7498-7502. [CrossRef] [PubMed]

115. Parenti, M.D.; Grozio, A.; Bauer, I.; Galeno, L.; Damonte, P.; Millo, E.; Sociali, G.; Franceschi, C.; Ballestrero, A.; Bruzzone, S.; et al. Discovery of Novel and Selective SIRT6 Inhibitors. J. Med. Chem. 2014, 57, 4796-4804. [CrossRef]

116. Sociali, G.; Galeno, L.; Parenti, M.D.; Grozio, A.; Bauer, I.; Passalacqua, M.; Boero, S.; Donadini, A.; Millo, E.; Bellotti, M.; et al. Quinazolinedione SIRT6 inhibitors sensitize cancer cells to chemotherapeutics. Eur. J. Med. Chem. 2015, 102, 530-539. [CrossRef]

117. Damonte, P.; Sociali, G.; Parenti, M.D.; Soncini, D.; Bauer, I.; Boero, S.; Grozio, A.; von Holtey, M.; Piacente, F.; Becherini, P.; et al SIRT6 inhibitors with salicylate-like structure show immunosuppressive and chemosensitizing effects. Bioorganic Med. Chem. 2017, 25, 5849-5858. [CrossRef]

118. Cardus, A.; Uryga, A.K.; Walters, G.; Erusalimsky, J.D. SIRT6 protects human endothelial cells from DNA damage, telomere dysfunction, and senescence. Cardiovasc. Res. 2013, 97, 571-579. [CrossRef] [PubMed]

119. Sun, W.; Chen, X.; Huang, S.; Li, W.; Tian, C.; Yang, S.; Li, L. Discovery of 5-(4-methylpiperazin-1-yl)-2-nitroaniline derivatives as a new class of SIRT6 inhibitors. Bioorg. Med. Chem. Lett. 2020, 30, 127215. [CrossRef] [PubMed]

120. Feldman, J.L.; Dittenhafer-Reed, K.E.; Kudo, N.; Thelen, J.N.; Ito, A.; Yoshida, M.; Denu, J.M. Kinetic and structural basis for Acyl-group selectivity and NAD+ dependence in sirtuin-catalyzed deacylation. Biochemistry 2015, 54, 3037-3050. [CrossRef]

121. Hu, J.; He, B.; Bhargava, S.; Lin, H. A fluorogenic assay for screening Sirt6 modulators. Org. Biomol. Chem. 2013, 11, 5213-5216. [CrossRef]

122. Bolivar, B.E.; Welch, J.T. Studies of the Binding of Modest Modulators of the Human Enzyme, Sirtuin 6, by STD NMR. ChemBioChem 2017, 18, 931-940. [CrossRef]

123. Madsen, A.S.; Andersen, C.; Daoud, M.; Anderson, K.A.; Laursen, J.S.; Chakladar, S.; Huynh, F.K.; Colaco, A.R.; Backos, D.S.; Fristrup, P.; et al. Investigating the Sensitivity of NAD(+)-dependent Sirtuin Deacylation Activities to NADH. J. Biol. Chem. 2016, 291, 7128-7141. [CrossRef]

124. Fatkins, D.G.; Monnot, A.D.; Zheng, W. N-epsilon-thioacetyl-lysine: A multi-facet functional probe for enzymatic protein lysine N-epsilon-deacetylation. Bioorganic Med. Chem. Lett. 2006, 16, 3651-3656. [CrossRef] [PubMed]

125. Sociali, G.; Liessi, N.; Grozio, A.; Caffa, I.; Parenti, M.D.; Ravera, S.; Tasso, B.; Benzi, A.; Nencioni, A.; Del Rio, A.; et al. Differential modulation of SIRT6 deacetylase and deacylase activities by lysine-based small molecules. Mol. Divers. $2020,24,655-671$. [CrossRef] [PubMed]

126. Zhang, X.; Khan, S.; Jiang, H.; Antonyak, M.A.; Chen, X.; Spiegelman, N.A.; Shrimp, J.H.; Cerione, R.A.; Lin, H. Identifying the functional contribution of the defatty-Acylase activity of SIRT6. Nat. Chem. Biol. 2016, 12, 614-620. [CrossRef]

127. Sociali, G.; Magnone, M.; Ravera, S.; Damonte, P.; Vigliarolo, T.; von Holtey, M.; Vellone, V.G.; Millo, E.; Caffa, I.; Cea, M.; et al. Pharmacological Sirt6 inhibition improves glucose tolerance in a type 2 diabetes mouse model. FASEB J. 2017, 31, 3138-3149. [CrossRef]

128. Yuen, L.H.; Dana, S.; Liu, Y.; Bloom, S.I.; Thorsell, A.G.; Neri, D.; Donato, A.J.; Kireev, D.; Schuler, H.; Franzini, R.M. A Focused DNA-Encoded Chemical Library for the Discovery of Inhibitors of NAD(+)-Dependent Enzymes. J. Am. Chem. Soc. 2019, 141, 5169-5181. [CrossRef] 